\title{
Multiple trauma management in mountain environments - a scoping review
}

\section{Evidence based guidelines of the International Commission for Mountain Emergency Medicine (ICAR MedCom). Intended for physicians and other advanced life support personnel}

G. Sumann', D. Moens², B. Brink ${ }^{3}$, M. Brodmann Maeder ${ }^{4}$, M. Greene ${ }^{5}$, M. Jacob ${ }^{6}$, P. Koirala ${ }^{7}$, K. Zafren ${ }^{8,9}$, M. Ayala ${ }^{10}$, M. Musi ${ }^{11}$, K. Oshiro ${ }^{12}$, A. Sheets ${ }^{13}$, G. Strapazzon ${ }^{14,15}$, D. Macias ${ }^{16}$ and P. Paal ${ }^{17^{*}}$ (i)

\begin{abstract}
Background: Multiple trauma in mountain environments may be associated with increased morbidity and mortality compared to urban environments.
\end{abstract}

Objective: To provide evidence based guidance to assist rescuers in multiple trauma management in mountain environments.

Eligibility criteria: All articles published on or before September 30th 2019, in all languages, were included. Articles were searched with predefined search terms.

Sources of evidence: PubMed, Cochrane Database of Systematic Reviews and hand searching of relevant studies from the reference list of included articles.

Charting methods: Evidence was searched according to clinically relevant topics and PICO questions.

Results: Two-hundred forty-seven articles met the inclusion criteria. Recommendations were developed and graded according to the evidence-grading system of the American College of Chest Physicians. The manuscript was initially written and discussed by the coauthors. Then it was presented to ICAR MedCom in draft and again in final form for discussion and internal peer review. Finally, in a face-to-face discussion within ICAR MedCom consensus was reached on October 11th 2019, at the ICAR fall meeting in Zakopane, Poland.

\footnotetext{
* Correspondence: peter.paal@icloud.com

${ }^{17}$ Department of Anaesthesiology and Intensive Care Medicine, St. John of God Hospital, Paracelsus Medical University, Salzburg, Austria

Full list of author information is available at the end of the article
}

C C The Author(s). 2020 Open Access This article is licensed under a Creative Commons Attribution 4.0 International License, which permits use, sharing, adaptation, distribution and reproduction in any medium or format, as long as you give appropriate credit to the original author(s) and the source, provide a link to the Creative Commons licence, and indicate if changes were made. The images or other third party material in this article are included in the article's Creative Commons licence, unless indicated otherwise in a credit line to the material. If material is not included in the article's Creative Commons licence and your intended use is not permitted by statutory regulation or exceeds the permitted use, you will need to obtain permission directly from the copyright holder. To view a copy of this licence, visit http://creativecommons.org/licenses/by/4.0/. The Creative Commons Public Domain Dedication waiver (http://creativecommons.org/publicdomain/zero/1.0/) applies to the data made available in this article, unless otherwise stated in a credit line to the data. 


\begin{abstract}
(Continued from previous page)
Conclusions: Multiple trauma management in mountain environments can be demanding. Safety of the rescuers and the victim has priority. A crABCDE approach, with haemorrhage control first, is central, followed by basic first aid, splinting, immobilisation, analgesia, and insulation. Time for on-site medical treatment must be balanced against the need for rapid transfer to a trauma centre and should be as short as possible. Reduced on-scene times may be achieved with helicopter rescue. Advanced diagnostics (e.g. ultrasound) may be used and treatment continued during transport.
\end{abstract}

Keywords: analgesia, Advanced Trauma Life Support, emergency medical services, first aid, haemorrhage, multiple trauma, shock, triage, wounds and injuries

\section{Introduction}

In mountain environments, multiple trauma, a life threatening injury involving at least one body region with an injury severity score (ISS) $\geq 16$, may be associated with increased prehospital time, a higher risk of accidental hypothermia, and a lower systolic blood pressure compared to urban trauma [1]. In a survey from Scotland, $78.4 \%$ of survivors were traumatised $(n=622)$, but only 12 (3.6\%) had sustained multiple trauma [2], indicating that multiple trauma is a rare condition. However, a multipletrauma patients requires more resources. Treatment cost may exceed US\$ 1 million [3] and quality of life and capacity to work are often permanently impaired [4]. Outcome from multiple trauma on a mountain may be worse than in an urban environment. It is necessary to optimise prehospital care of multiple trauma patients to avoid poor outcomes related to delayed or incorrect treatment. No specific guidelines exist for the management of multiple trauma in mountain environments. Despite numerous medical and technological advances, care of multiple trauma patients in a mountain environment remains challenging. Bad weather, difficult terrain, poor visibility, and limited rescue personnel and transport options may affect patient outcomes. Every rescue is different. Rescuers must exercise flexibility in selecting the transport options best suited to each case. The objective of this review is to provide evidence based guidance to assist rescuers in the management of multiple trauma in mountain environments.

\section{Methods}

For this PRISMA Scoping Review (PRISMA-ScR) [5], a working group was formed at the ICAR meeting in Soldeu, Andorra in October 2017. Subgroups of coauthors were invited, based on their interests and knowledge, to collaborate under the coordination of a lead author for each subtopic. A PRISMA-ScR checklist is provided (Supplemental Table 1). Population Intervention Comparator Outcome (PICO) questions were developed and evidence mapped according to clinically relevant challenges and PICO questions (Supplemental file 1). All articles published on or before September 30th 2019, in all languages, were included. Searches of PubMed and the Cochrane Database of Systematic Reviews and hand searching of relevant studies from the reference lists of included articles were performed (Supplemental file 2). Recommendations were developed and graded according to the evidence-grading system of the American College of Chest Physicians (Table 1) [6]. The manuscript was written and discussed by the coauthors. It was presented in draft and again in final form for discussion and internal peer review within ICAR MedCom. Finally, in a face-to-face discussion of ICAR MedCom, consensus was reached on October 11th 2019 at the ICAR meeting in Zakopane, Poland.

\section{Results}

Two-hundred forty-seven articles were included in this review. Eighty-four recommendations were developed (Supplemental file 3).

\section{Discussion}

Injury patterns of patients with multiple trauma in the mountains

The injury patterns of multiple trauma vary according to the terrain (e.g. grassy or rocky ground), protective equipment and techniques (e.g. helmet, rope, belaying) and the activity. For instance, critical injuries in climbing often involve the pelvis and chest [7], canyoning accidents the lower and upper extremities [8], and mountain biking, winter, and aviation sport injuries the head and thoracolumbar vertebral column [9-11].

\section{Challenges in mountain rescue}

Accidents in the mountains create challenges that are not found in most urban scenarios. Trauma victims can be difficult to locate and extricate because of the terrain. Bad weather can impede rescue efforts and limit the delivery of on-site patient care. Environmental factors may demand deviation from normal patterns of care provided in an urban environments. Evacuation to definitive care can be greatly delayed due to travel over difficult terrain and bad weather. Medical response in mountainous terrain can also be greatly delayed compared to an urban 
Table 1 Classification scheme for grading evidence [6]

Grade Strong recommendation, high quality evidence, benefits clearly outweigh risks and burden or vice versa
1A
Grade
1B

setting. Mountain victims may not receive care within the same time frame as in an urban setting because of the location. This article focuses on helicoptersupported mountain rescue missions because in many developed countries (e.g. Austria >98\%), as well as in some developing countries, the large majority of multiple trauma patients are rescued by HEMS. Groundbased mountain rescue services are still necessary during conditions that prevent helicopter flights, such as bad weather, darkness, when night vision goggles are not available, and high altitude. Technical possibilities and human resources may be very limited during ground rescue missions. In ground rescue missions, only basic equipment may be available. The physical and psychological challenges may be extraordinary. Trauma mortality is not necessarily higher with prehospital times longer than $60 \mathrm{~min}$ except for patients in haemorrhagic shock $[12,13]$. The goal is to provide the best possible care throughout the rescue effort, given the unique situation and based on the principles described in these recommendations.

Recommendations: Consider terrain, weather, transport conditions and limited resources when treating a multiple trauma patient in the mountains (1C).

\section{Rescuer safety}

The safety of the rescuers is the first principle of rescue (Fig. 1). Rescuers should be able to move safely in hazardous mountain terrain. Helmets can reduce the likelihood and severity of traumatic brain injury (TBI). Mountain rescuers should wear helmets to protect against TBI and should use additional safety equipment to prevent injuries. On-site patient care may be hazardous to both patients and rescuers, because of steep or slippery terrain, rock-, ice- or snowfall, avalanches, and low visibility. Rescuers must consider potential hazards including transport to and from the scene, access to the scene, clothing and equipment for the rescuers, and reliable communications with other agencies and team members. Rescuers must also use personal protection from body fluid exposures and be prepared to handle immediate life threatening conditions. The decision to 'stabilise on site and prepare for transport' versus a 'grab and go' approach will necessarily be made on a case-bycase basis. In hazardous conditions, it may be necessary to evacuate a casualty from the accident site as rapidly as possible before any medical treatment has been given, even if there are critical injuries [14].

Recommendations: On-site safety of rescuers takes precedence over all other considerations (1C). Wear helmets to protect against TBI (1B) and use additional safety equipment to prevent injuries and infections (1C). In a hazardous environment, consider a strategy of 'grab and go' rather than 'stabilise on site.' (1C).

\section{Critical bleeding (Cr)}

In contrast to patients with multiple trauma in military operations, patients in the mountains with multiple trauma very rarely sustain life threatening limb haemorrhage that can be treated with relatively simple measures, such as a tourniquet. Rather, these patients often sustain blunt injuries with bleeding from internal organ injuries that can only be treated surgically (e.g. by damage control surgery or interventional radiology).

In patients with multiple trauma, control of massive external haemorrhage with methods such as compression, haemostatic agents, or tourniquets, takes priority over other components of ABCDE because massive external haemorrhage leads to death most rapdily [15]. In tactical or military medicine this is known as the critical bleeding or the eXsanguination ABCDE approach [16] (crABCDE or XABCDE).

\section{Airway (A) and cervical spine (c-spine)}

Maintaining an open airway is the second essential step in the treatment of trauma patients. Oxygen is recommended for trauma patients, especially at high altitude (above $2500 \mathrm{~m}$ ), in order to preserve normoxia [17]. Available oxygen may be limited, especially during long or technically difficult rescues. A suction device must be 


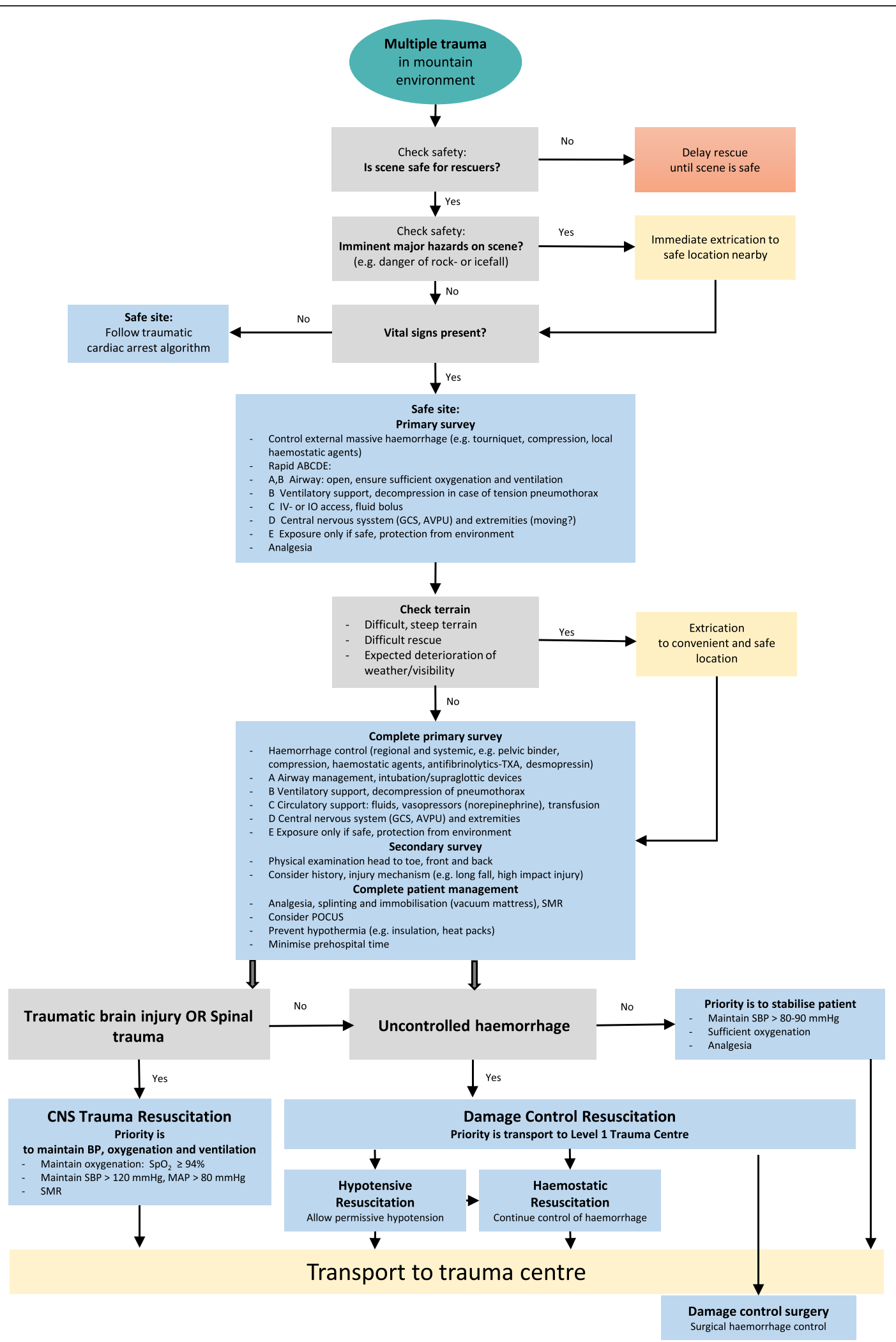

Fig. 1 Treatment of multiple trauma in mountain environments algorithm. ABCDE; Airway, Breathing, Circulation, Disability, Exposure; IV; intravenous; IO; intraosseus; GCS: Glasgow Coma Scale; AVPU: Alert Voice Pain Unresponsive; TXA; tranexamic acid; SMR: spinal motion restriction; POCUS: point of care ultrasound; BP: blood pressure; SBP: systolic blood pressure; $\mathrm{SpO}_{2}$ : oxygen saturation by pulse oximeter; MAP: mean arterial pressure; $\mathrm{mmHg}$; millimetres of mercury 
ready at all times [18]. An obstructed airway requires immediate airway management. To open the airway, the initial action should be a jaw thrust, avoiding excessive movement of the cervical spine. Indications for advanced airway management include apnoea, agonal respirations, severe thoracic trauma, and TBI with seriously impaired gas exchange [18]. Advanced airway management prior to extrication by hoist or long line carries a risk of dislodging the airway device or hypoventilating the patient [19]. Providing a definitive airway can be difficult. Video laryngoscopy with a bougie may facilitate tracheal intubation [20]. Prehospital tracheal intubation should only be performed by experienced rescuers. In austere environments, use of supraglottic devices may be superior to tracheal intubation [21]. When a definitive airway is required and tracheal intubation is not possible, creation of a surgical airway with a cricothyrotomy may be necessary if supraglottic airway insertion and bag-valve mask ventilation fail. Ventilation with a bag-valve mask or a supraglottic airway is often as effective as tracheal intubation [22]. Immediately after establishment of an advanced airway (a tracheal tube or supraglottic airway), capnography should be used to confirm correct placement and to achieve normal ventilation. In prolonged rescue missions, bag-valve mask ventilation should only serve as a bridge to a protected airway.

Immobilisation of the c-spine is not necessarily recommended for all blunt trauma patients (Table 2) [24-26] and should not be performed in neurologically intact patients with penetrating trauma [23, 27-33]. A clinical decision rule, such as NEXUS or the Canadian C-spine Rule, should be used to avoid secondary spinal injury [33-36]. Prehospital clearance of the c-spine in children ( $\leq 8$ years, although not uniformly defined) is not recommended [37-40]. Methods to immobilise the c-spine may include manual in-line stabilisation, SAM splints, or cervical collars [41]. Cervical collars must be applied correctly [42], with special attention to maintaining venous return [23, 43-47]. Spinal injury is covered under Disability.

Recommendations: Provide oxygen (2B), especially at high altitude (above $2500 \mathrm{~m}$ ) (1A). Rescuers should be competent in opening and clearing an airway, and in

Table 2 Patients who do not require immobilisation must meet all five of the following criteria [23]

- awake and alert,
- not intoxicated
- no painful distracting injuries
- no tenderness at the posterior midline along the cervical spine
- no focal neurologic deficit

All other patients require spinal motion restriction with stabilisation of the entire body, unless they have an $A B C D$ instability, in which case minimal spinal motion restriction and immediate transfer may be preferred maintaining a patent airway $(1 \mathrm{C})$. Only experienced rescuers should perform prehospital tracheal intubation (1B). Consider advanced airway management if gas exchange is seriously impaired (2B). Be cautious with advanced airway management prior to extrication by hoist, because the artificial airway may be dislodged or the patient may be hypoventilated (1C). Consider using a video laryngoscope and an introducer to facilitate tracheal intubation (1B), or a supraglottic device as an alternative to tracheal intubation (2A) Tracheal intubation of a child should only be performed by an experienced rescuer. Otherwise, ventilate with a bag-valve mask (2B). After establishing an advanced airway, use capnography to confirm correct placement and to maintain normal ventilation (2B). Do not immobilise the $\mathrm{c}$-spine of a blunt trauma patient who does not meet criteria for ccollar placement according to a validated decision rule (1A). Do not immobilise the c-spine of a neurologically intact patient with penetrating trauma (1A). Do not clear the c-spine in children in a prehospital environment (1C). The c-spine may be immobilised using manual inline stabilisation, a SAM splint, or a cervical collar (1B).

\section{Breathing (B)}

Normoxia and normocapnia are optimal to support physiological organ function. Ventilatory support is desirable if the patient is not able to maintain normoxia with supplementary oxygen or if hypercapnia may have deleterious effects, as in a hypoventilating patient with TBI. With the lowest possible oxygen flow to preserve supplies, aim for oxygen saturation $\geq 94 \%$ ( $88 \%$ in patients with chronic pulmonary disease). Avoid hyperoxia, as it may decrease survival [48]. Once an advanced airway is established, normal ventilation should be achieved with lung-protective ventilation according to ideal body weight, monitored by end-tidal carbon dioxide measurement (capnometry) and pulse oximetry [49]. Acute respiratory failure after severe trauma may be caused by a severe chest injury, such as flail chest, lung contusions or lacerations, or tension pneumothorax. Acute respiratory failure may also occur after TBI or spinal trauma, because of respiratory paralysis, aspiration, or airway obstruction secondary to decreased level of consciousness.

Recommendation: Establish normal ventilation with lung-protective ventilation and establish normoxia and normocapnia in TBI patients (1A).

\section{Thoracic injury}

Multiple trauma is frequently associated with blunt thoracic trauma [50]. The main symptoms of blunt thoracic trauma are pain and difficulty breathing. Initial assessment should include pulse oximetry and assessment of breathing to identify respiratory distress [51]. Severe pain from fractured ribs may compromise ventilation. 
Effective analgesia and oxygen administration may improve ventilation and oxygenation. A noncritical pneumothorax or haemothorax may remain undiagnosed without risk to the patient. Consideration must be given to the expansion of trapped gas in the pneumothorax if the helicopter must gain substantial elevation during the evacuation [52]. If oxygenation does not improve or deteriorates and severe respiratory or circulatory compromise occurs, it is critical to diagnose a tension pneumothorax and to perform an immediate decompression of the pleural cavity [53]. Needle decompression in the second or third intercostal space in the midclavicular line can be rapidly and easily performed as the first step in treatment, but has a considerably higher failure rate than tube thoracostomy [54]. Tube thoracostomy is superior to needle decompression, although it is not without risks [53, 55]. Pigtail catheters are increasingly used because they are minimally invasive and have a lower complication rate than tube thoracostomy. They may become the prehospital intervention of choice in uncomplicated pneumothorax $[56,57]$. The prehospital use of a minithoracostomy, a skin incision followed by blunt finger dissection without a trocar, may have the lowest complication rate, but can create a sucking chest wound in a nonventilated patient [58]. Massive haemothorax may cause both severe respiratory distress and significant blood loss, necessitating immediate evacuation to a trauma centre. In several HEMS systems, thoracostomies are performed routinely in anaesthetized patients receiving positive pressure ventilation. In remote mountain emergency operations, during a long rescue, a thoracostomy may be required as a lifesaving procedure without positive pressure ventilation. If a thoracostomy is performed on a patient without a tension pneumothorax, negative pressure ventilation (spontaneous breathing) may lead to accumulation of a simple pneumothorax with respiratory compromise.

Recommendations: Identify respiratory distress and use a pulse oximeter (1B). Consider the potential critical expansion of a pneumothorax during helicopter evacuation when substantial elevation gain is necessary (1B). If severe respiratory or circulatory compromise occurs, consider the cause to be a tension pneumothorax. Immediately decompress the pleural cavity (1B) with a minithoracostomy (1B) or pigtail catheter (2B).

\section{Circulation (C)}

Severe haemorrhage is the second leading cause of death, after TBI [59]. Decreased cardiac output and blood pressure reduce tissue oxygen delivery.

\section{Therapeutic targets}

Prioritise haemorrhage control. Maintain oxygenation and perfusion using clinical and ultrasonographic findings [60] with a goal of mean arterial blood pressure (MAP) $\sim 65 \mathrm{mmHg}$ in previously normotensive patients $[61,62]$.

\section{Monitoring in mountain environments}

Pulse oximetry and blood pressure often are readily obtainable. Perfusion can be measured clinically by assessing consciousness and capillary refill (limited in cold and with anaemia). Blood pressure measurement only provides a surrogate marker of perfusion and oxygen delivery. With noncompressible haemorrhage, allow for permissive hypotension [61] and prioritise rapid transport.

\section{Bleeding control}

\section{Nonpharmacologic methods}

First, attempt direct manual compression. Continued extremity bleeding should be controlled with a tourniquet [63-65]. Modern tourniquets can decrease haemorrhage, prevent shock, decrease limb loss caused by ischaemia, and permit rapid extrication [66, 67]. Mortality increases if tourniquet use is delayed until trauma-centre arrival [68]. Windlass-style tourniquets (eg CAT or SOFTT tourniquets) are optimal. Tourniquets are superior to direct pressure in severe extremity exsanguination. Usually they are left in place for 2-6 h [61]. It is best to release the tourniquet only after arrival to definitive care. Tourniquet-related complications are rare for tourniquets applied less than $2 \mathrm{~h}$. Complications may also be related to degree of tissue injury [69]. There are anecdotal reports describing complications. Some guidelines recommend checking for bleeding every two hours [70]. Control of noncompressible haemorrhage with expandable sponges is a novel method [71]. Junctional tourniquets may control haemorrhage in inguinal and axillary areas where standard tourniquets are not effective [72]. Temporary aortic occlusion with resuscitative balloon occlusion of the aorta (REBOA) has been described for internal abdominopelvic haemorrhage, but substantial training and resources are required [73]. REBOA is a complex technique, which only a few highly advanced HEMS may be able to offer. The use of ultrasound may make REBOA more accurate and safer. The technique and pitfalls have been reviewed in detail elsewhere [74]. Pelvic binders close the pelvic ring [75, 76]. Pelvic binders may have an effectiveness of $70 \%$ in stabilizing the pelvis [77, 78]. Training is required. Binders must be carefully positioned to be effective.

\section{Pharmacologic methods}

Antifibrinolytics Coagulopathy increases mortality in severe exsanguination. Haemorrhagic death [79-84] and multi-organ failure with severe shock [85] decrease with 
administration of tranexamic acid TXA) within $3 \mathrm{~h}$ after trauma, without increasing the risk of thrombosis [79]. The dose is $1 \mathrm{~g}$ intravenously (IV) over $10 \mathrm{~min}$, followed by $1 \mathrm{~g}$ IVover $8 \mathrm{~h} \mathrm{[61].}$

Platelet aggregators Desmopressin enhances platelet aggregation. It is helpful for patients on platelet inhibitors [86-93] or with von Willebrand disease [94]. The dose is $0.3 \mathrm{mcg} / \mathrm{kg}$ IV over $30 \mathrm{~min}$ [95]. Desmopressin should not be given routinely in bleeding trauma patients, but should be considered in patients with hypothermia-induced coagulopathy [96]. Desmopressin increases platelet aggregation in acidotic hypothermia [97]. In isolated hypothermia, the recommended dose is $1.5 \mathrm{mcg}$ subcutaneously [96]. With acidosis and hypothermia the dose is $0.3 \mathrm{mcg} / \mathrm{kg}$ IV [97]. Desmopressin does not increase the risk of thrombotic events [98].

Factor concentrates Reversal of trauma-induced coagulopathy with fresh frozen plasma (FFP) can fail from lack of fibrinogen. Empiric administration of $3 \mathrm{~g}$ of fibrinogen concentrate IV decreased mortality in multiple trauma in a Japanese study [99]. Fibrinogen concentrate may decrease blood transfusion needs, multi-organ failure and mortality [100]. Reversal of vitamin $\mathrm{K}$ inhibition with four-factor prothrombin complex concentrate, at a dose of $25 \mathrm{U} / \mathrm{kg} \mathrm{IV}$, is promising for geriatric trauma patients, with or without intracranial haemorrhage, on warfarin or direct oral anticoagulant therapy [101-104].

Haemostatic dressings are superior to plain gauze. Biocompatible chitosan-impregnated gauze (Celox or ChitoGauze Pro) is best. It links platelets and red blood cells, forming a mucoadhesive barrier after 2-5 min of direct pressure [105]. HemCon bandages are less effective in complex wounds. Zeolite granules are rarely used because of possible exothermic reactions. Zeolite sponges have a lower risk of burns and are less likely to embed inorganic material in the wound [106] (Table 3). Recently, bioabsorbable cellulose (e.g. WoundClot), with embedded coagulation factors, has been introduced. The haemostatic effects are promising [107].

\section{IV access}

At least one large bore IV is required in a multiple trauma patient who will require large volumes of fluid. Intraosseous volume replacement is slower. When fluid and drug administration are necessary, IO access should be obtained if IV access cannot be established after three attempts.

\section{Volume replacement, blood products, and vasopressors} Rapid volume replacement (Table 4) can restore cardiac preload and mitigate the effects of haemorrhage, if provided judiciously. Helicopters have transported uncrossmatched $\mathrm{O}$ negative packed red blood cells (PRBCs) to mountain rescue and other prehospital scenes. No transfusion reactions have been reported. Improved outcomes have not been reported in civilian rescue [108-111], but are common in military medicine [112]. In a TBI patient without critical bleeding, vasopressors may help maintain cerebral perfusion pressure if MAP decreases during prolonged transport. Norepinephrine is the preferred vasopressor. It should be given via a large peripheral vein, Uses of fluids and other adjuncts for haemorrhagic shock are shown in Table 4 [61, $66,113]$.

\section{Recommendations}

General principles. Stop haemorrhage (1A) and maintain oxygenation and perfusion (MAP $\geq 65 \mathrm{mmHg}$ in previously normotensive patients) (1C). With uncontrolled haemorrhage, allow permissive hypotension (1B). Rapid transport may be critical (1B).

Bleeding Control. Nonpharmacologic methods. First, attempt direct manual compression (1A). For uncontrolled extremity bleeding use a modern tourniquet with a windlass to control bleeding (1B) and facilitate extrication (1B). Release the tourniquet only after arrival to definitive care (2B). Do not release the tourniquet to check bleeding. (2C). Consider control of noncompressible truncal haemorrhage with expandable sponges and junctional tourniquets for axillary and inguinal areas (2C). For pelvic fractures, use a pelvic binder to close the pelvic ring $(2 \mathrm{C})$.

Bleeding Control. Pharmacologic methods. Administer TXA within $3 \mathrm{~h}$ post-trauma (1B). Consider desmopressin for patients on platelet inhibitors, with von Willebrand disease (2A), and with hypothermiainduced coagulopathy (2C). Consider fibrinogen concentrate administration rather than fresh frozen plasma (FFP) (2B). Consider prothrombin factor concentrate administration (2A). Consider reversal of vitamin $\mathrm{K}$ inhibition $(2 \mathrm{~A})$ or direct oral anticoagulant therapy (2C). Consider using haemostatic dressings rather than plain gauze (1C).

IV access, volume replacement, and vasopressors. Establish at least one large bore IV for administration of fluid (1C). Establish IO access if IV access is impossible after three attempts when fluid and drug administration are required (1C). Use judicious rapid volume replacement to restore cardiac preload (1A), but be aware of detrimental effects of cold fluids such as dilution and hypothermia-induced coagulopathy. Consider norepinephrine in TBI patients without critical bleeding to maintain cerebral perfusion pressure during prolonged transport (1C). 
Table 3 Summary of haemostatic bandages, adapted from [105]. Gen denotes generation, RBCs red blood cells

\begin{tabular}{|c|c|c|c|c|}
\hline Manfacturer & Gen & Mechanism of action & Form & Application \\
\hline $\begin{array}{l}\text { Celox gauze, MedTrade } \\
\text { Products Ltd., Crew, UK }\end{array}$ & $3 \mathrm{rd}$ & $\begin{array}{l}\text { Cross-links RBCs to form } \\
\text { mucoadhesive barrier }\end{array}$ & $\begin{array}{l}\text { Chitosan rolled gauze Z-fold, } 3 \text { in. } \\
\times 10 \mathrm{ft}\end{array}$ & Packed into wound, 3 min direct pressure \\
\hline $\begin{array}{l}\text { CeloxGauze Pro, HemCon } \\
\text { Medical Technologies, } \\
\text { Portland, OR }\end{array}$ & $3 \mathrm{rd}$ & $\begin{array}{l}\text { Cross-links RBCs to form } \\
\text { mucoadhesive barrier }\end{array}$ & $\begin{array}{l}\text { Chitosan gauze Z-fold, } 12 \mathrm{ft} \text {. } \\
\text { length }\end{array}$ & Packed into wound, 2-5 min direct pressure \\
\hline $\begin{array}{l}\text { XStat, RevMedx Inc., } \\
\text { Wilsonville, OR }\end{array}$ & $3 \mathrm{rd}$ & $\begin{array}{l}\text { Cellulose sponges coated with } \\
\text { chitosan to assist with a } \\
\text { mucoadhesive barrier }\end{array}$ & $\begin{array}{l}92 \text { flat, circular, compressed mini } \\
\text { sponges packaged in a } 60 \mathrm{~mL} \\
\text { syringe applicator }\end{array}$ & $\begin{array}{l}\text { The applicator has a small diameter insertion } \\
\text { device available for use in wounds with } \\
\text { narrow wound tracts }\end{array}$ \\
\hline
\end{tabular}

\section{Disability (D)}

\section{Traumatic brain injury}

The combination of TBI and multiple trauma is a predictor of poor outcome [114].

\section{Airway management}

Increases in the severity and duration of secondary insults correlate with worse outcomes [115]. Maintaining an open airway may help to minimise secondary brain injury. In severe TBI, supplementary oxygen may help to avoid secondary brain injury. If the rescuers have only basic skills, simple airway procedures may improve survival [116]. Tracheal intubation has caused increased mortality in some trauma systems, probably because rescuers lacked adequate airway management skills [116119]. Improved outcomes have been reported for tracheal intubation in severe TBI when experienced providers deliver care using rapid sequence intubation with neuromuscular blocking agents [119-121].

\section{Ventilation and oxygenation}

Ventilation should be assessed clinically (rate, depth, effort). Patients should be monitored by pulse oximetry and waveform capnography. Hypoxia $\left(\mathrm{SpO}_{2} \leq 94 \%\right)$, hyperventilation $\left(\mathrm{ETCO}_{2}<35 \mathrm{mmHg}-<4.5 \mathrm{kPa}\right)$ and hypoventilation $\left(\mathrm{ETCO}_{2}>45 \mathrm{mmHg}->6 \mathrm{kPa}\right)$ are associated with worse outcomes [122, 123]. Achieving normocapnia in patients with multiple trauma can be challenging. Continuous monitoring with capnography can reduce hypo- and hyperventilation in TBI patients $[49,115,124]$. Rescuers should attempt to maintain normoxia $\left(\mathrm{SpO}_{2}\right.$ 95-98\%) and normocapnia $\left(\mathrm{ETCO}_{2} 35-45\right.$ $\mathrm{mmHg}-4.5-6 \mathrm{kPa}$ at sea level).

\section{Hypotension}

It is essential to control haemorrhage in order to minimise secondary TBI caused by hypotension. The injured brain loses autoregulation, resulting in secondary ischaemic damage. Hypotension (systolic blood pressure $[\mathrm{SBP}]<110 \mathrm{mmHg}$ ) increases morbidity and

Table 4 Fluid resuscitation and adjuncts in haemorrhagic shock. AKI: acute kidney injury; CNS: central nervous system; HES: hydroxyethyl starch solution; ICU: intensive care unit; MA: metabolic acidosis; PRBCs: packed red blood cells; TBI: traumatic brain injury

\begin{tabular}{|c|c|c|c|}
\hline Agent & Advantages & Disadvantages & Notes \\
\hline $\begin{array}{l}\text { CRYSTALLOIDS } \\
0.9 \% \text { Normal Saline } \\
\text { ('unbalanced') }\end{array}$ & $\begin{array}{l}\text { Readily available, familiar; compatible } \\
\text { with most medications and blood } \\
\text { products }\end{array}$ & $\begin{array}{l}\text { Not 'physiologic' (high chloride } \\
\text { load); excess administration leads to } \\
\text { AKI and MA (2C) }\end{array}$ & Bolus to effect after bleeding controlled. (1 A) \\
\hline $\begin{array}{l}\text { Ringer's lactate/ } \\
\text { acetate ('balanced'); } \\
\text { Plasmalyte }\end{array}$ & Readily available; 'physiologic' & $\begin{array}{l}\text { Slightly hypotonic; excess } \\
\text { administration worsens TBI (1C) }\end{array}$ & $\begin{array}{l}\text { May reduce incidence of } \mathrm{AKI} \text { and mortality } \\
\text { in ICU. Bolus with control of bleed ( } 1 \mathrm{~A})\end{array}$ \\
\hline $\begin{array}{l}\text { Hypertonic saline } \\
\text { solution }\end{array}$ & $\begin{array}{l}\text { Low weight and volume (easier to } \\
\text { transport); thermal stability; safe }\end{array}$ & $\begin{array}{l}\text { May interfere with coagulation in } \\
\text { patients with severe TBI }\end{array}$ & $\begin{array}{l}\mathrm{NaCl} \text { concentration }>0.9 \% \text {; may expand } \\
\text { volume, no long term survival benefit or } \\
\text { improved CNS outcome vs. } \mathrm{NaCl} 0.9 \%\end{array}$ \\
\hline $\begin{array}{l}\text { COLLOIDS } \\
\text { Albumin, hydroxyethyl } \\
\text { starch (HES), Dextran }\end{array}$ & Used as volume expander & $\begin{array}{l}\text { Expensive; no proven mortality } \\
\text { benefit. HES may increase harm in } \\
\text { some subgroups. }\end{array}$ & $\begin{array}{l}\text { Prehospital data still rare. HES may impair } \\
\text { coagulation }\end{array}$ \\
\hline $\begin{array}{l}\text { PACKED RED BLOOD } \\
\text { CELLS / PLASMA / } \\
\text { WHOLE BLOOD }\end{array}$ & $\begin{array}{l}\text { May improve survival or physiology, for } \\
\mathrm{Hb}<7 \mathrm{~g} / \mathrm{dL} \text {; lyophilised plasma is used } \\
\text { in damage control }\end{array}$ & $\begin{array}{l}\text { Inconvenient in out-of-hospital en- } \\
\text { vironment; ARDS/ transfusion } \\
\text { reactions }\end{array}$ & $\begin{array}{l}\text { Used by few centres; PRBCs:plasma: platelets } \\
1: 1: 1 \text { or } 2: 1: 1 \text { (1B), or fibrinogen } 0.5 \mathrm{~g} \text { per unit } \\
\text { PRBCs (1C) in hospital }\end{array}$ \\
\hline VASOPRESSORS & $\begin{array}{l}\text { Use after adequate volume } \\
\text { replacement (1C), Push-dose pressors } \\
\text { simple; cardiac dysfunction: } \\
\text { epinephrine }\end{array}$ & $\begin{array}{l}\text { Does not treat cause; uncertain } \\
\text { long-term benefit; dosing errors,; un- } \\
\text { certain benefit (haemorrhage) }\end{array}$ & $\begin{array}{l}\text { Constricts capacitance vessels; used in } \\
\text { airway management / TBI with hypotension }\end{array}$ \\
\hline
\end{tabular}


mortality in TBI [125]. Mortality is higher when hypoxia and hypotension are combined [115]. Outcomes worsen with more episodes, increased severity, and longer duration of hypotension. In TBI, the traditional definition of shock (SBP $<90 \mathrm{mmHg}$ ) underestimates the effect of hypotension [126-128]. Patients with moderate to severe TBI should be considered hypotensive with $\mathrm{SBP}<110 \mathrm{mmHg}[127,128]$. In a retrospective registry study, mortality increased $4.8 \%$ for every $10 \mathrm{mmHg}$ decrease in SBP when SBP was $<110 \mathrm{mmHg}[129,130]$. In critical patients with TBI, a target SBP of $120 \mathrm{mmHg}$ effectively minimised secondary insults [131]. The target SBP for cerebral resuscitation in TBI should be $\geq 110 \mathrm{mmHg}$. In multiple-trauma patients with TBI, the need to maintain cerebral perfusion pressure with increased SBP conflicts with the use of permissive hypotension. This conflict has not been studied in adults. In children timely haemodynamic resuscitation, to treat TBI, improves outcomes [132]. The use of hypertonic saline rather than standard fluids does not improve outcomes [133]. In the mountains, especially on ground rescue missions, small volumes of hypertonic saline may be more practical than standard fluids [134]. The value of prehospital vasopressors remains uncertain [135], but they may be helpful to maintain adequate SBP. Temperature management to avoid hypothermia improves haemorrhage control to minimise secondary injuries [136].

\section{Methods to decrease intracranial pressure (ICP)}

Use of mannitol or hypertonic saline can reduce ICP temporarily, for similar periods of time [136-138] Neither improves outcomes [139]. Elevation of the head to $30^{\circ}$ may decrease intracranial pressure in paediatric TBI [140], A Cochrane database systematic review concluded that the evidence to support beneficial clinical outcomes was very low quality [141]. Head elevation is the preferred position, but should not delay timely rescue and evacuation [141].

\section{Tranexamic acid to decrease haematoma expansion}

The use of TXA within $3 \mathrm{~h}$ of TBI decreases mortality without increasing adverse events [142, 143].

\section{Hypothermia and TBI}

Hypothermia is independently related to poor outcomes in TBI $[144,145]$. Increased mortality with hypothermia in multiple trauma is likely related to coagulopathy causing increased haemorrhage and hypotension, with decreased cerebral perfusion pressure. There is no evidence to support the use of early therapeutic hypothermia in the management of TBI [146-148].
Recommendations: Assess ventilation clinically (1C) and monitor patients with pulse oximetry to minimise hypoxia (1C). Use capnography to maintain normocapnia (1C). Maintain systolic blood pressure $\geq 110 \mathrm{mmHg}$ (2C). Expedite rescue. Do not delay evacuation by attempting to maintain elevation of the head (1C). Administer TXA within $3 \mathrm{~h}$ after trauma (1A). Avoid hypothermia (1C).

\section{Spinal injury}

Careful positioning and transport of patients with spinal injury in rough terrain may be challenging, but is important to avoid secondary injury. Spinal injury can involve only the bony spinal column or can be associated with spinal cord injury. Secondary insults result from movement, hypoxia, hypotension, and haematoma compressing the spinal cord. There are questions about the efficacy and safety of traditional spinal immobilisation for all trauma patients [149-152]. A more selective approach may be better $[149,153,154]$. Spinal motion restriction in the mountains may interfere with life saving interventions and may delay transport to definitive care. Spinal motion restriction is necessary for any patient with an altered level of consciousness [155]. A clinical decision rule should be used to identify patients at risk of significant spinal injury [33-36].

Manual in-line stabilisation with a 'trapezius squeeze' hold is as effective as a cervical collar to protect the cspine during movement and during tracheal intubation [156]. Cervical collars are not necessary for all patients. They do not eliminate all movement. Adverse effects, including interference with breathing and venous compression may contribute to physiologic compromise of a patient with multiple trauma [25, 44, 157, 158]. Spinal motion restriction can be achieved using a combination of manual in-line stabilisation, head blocks, and hard or soft transfer devices [159]. Unstable patients with multiple trauma should be handled as little as possible. Logrolling is of limited diagnostic value in most circumstances. Use of a manual vertical lift or a scoop stretcher limits spinal motion [160]. A vacuum mattress is a stable transfer device that provides comfort and protects against pressure necrosis during prolonged transport [161-164]. For extrication and transport, a vacuum mattress should be used in a horizontal rescue bag or stretcher. When horizontal extrication is not possible, as in narrow crevasses, a Kendrick Extrication Device (KED) or newer devices such as NEXT can be used to stabilise the spine in a sitting position [165].

Recommendations: Immobilise the spine of all multiple trauma patients with altered level of consciousness (1C). Use a clinical decision rule to identify patients at risk from secondary spinal injury and only if positive immobilise the spine (1B). Limit spinal motion with a 
combination of manual stabilisation, head blocks, and hard or soft transfer devices (1C). Choose techniques that require minimal handling (1C). Do not log roll unstable trauma patients (1C). Consider a vacuum mattress for a long comfortable transfer (1C). Consider a KED or similar device for extrication in a non-horizontal position (1C).

\section{Environment and exposure (E)}

Prehospital assessment of the type and severity of multiple trauma should guide treatment, including the choice of destination, especially in life-threatening cases. Physical examination may be limited by adverse environmental conditions [166] and cannot be performed reliably without some degree of exposure. Exposure may cause or worsen hypothermia, a common condition in trauma patients that contributes to coagulopathy and acidosis [166-168]. History and physical exam alone have a low accuracy in detecting injuries in blunt trauma, missing almost half of injuries, even in a hospital environment [169]. Prehospital injury assessment by physicians can miss up to one-third of significant injuries [170]. The value of exposure should be weighed against the risk of hypothermia. Examination should be performed sequentially, by body region, avoiding heat loss and preserving insulating clothing.

Recommendations: Consider whether exposure will be helpful. (1C). Sequentially examine by body region, avoiding heat loss and preserving insulating clothing (2C).

\section{First aid, splinting and immobilisation}

Injuries of the extremities are the most common cause of evacuation by organised mountain rescue services in Europe and the US. In a survey from Scotland, $50 \%$ of the survivors suffered from lower limb trauma [2]. Similarly, in the US, sprains, strains, and fractures were the most common medical incidents amongst recreational wilderness medicine expeditions, with fractures being the most frequent cause for evacuation [171]. In a multiple trauma patient, extremity injuries may be associated with additional life-threatening injuries. Lifesaving interventions, following crABCDE, should precede other care. Extremity injuries that are not life threatening, should be immobilised only after the patient has been stabilised [14].

Although splinting and immobilisation have been described since ancient times, accepted practise has been established more by time than by high quality randomised controlled trials. Benefits of fracture reduction and immobilisation include pain control, decreased blood loss, prevention of conversion from closed to open fracture, and protection from further injury [172]. Early immobilisation, reduction, and splinting reduce pain in patients with closed fractures treated in the emergency department. Splinting can cause harm if not done correctly. Some interventions, including traction splints for femur fractures, may cause morbidity even when properly applied. In patients with multiple trauma, contraindications to traction splinting for femur fractures are common. Contraindications include non-midshaft location and associated knee or tibia-fibula fractures. Most patients with multiple trauma should be extricated on vacuum mattresses or spine boards [173, 174]. Spine boards have hard surfaces and should only be used for extrication. They are not suitable for transport. Spine boards can cause tissue necrosis even when used for relatively short time periods. Patients with hypotension or hypothermia may be at increased risk of tissue necrosis.

Immobilisation of extremity injuries should follow standard splinting procedures, including the use of sufficient padding, immobilising the joints above and below the injury, and neurovascular checks before and after splinting. Traction splinting for midshaft femur fractures should be used only if needed for pain control, haemorrhage reduction, or for immobilisation if simple splinting does not suffice. The choice of splinting device is subject to many factors including the part of the body to be splinted, cost, weight, compatibility with other rescue equipment, and regional preferences (Table 5) [175]. Whilst there have been no randomised comparisons of splinting devices,vacuum splints have been proven effective and, despite their weight, have been widely adopted [163, 165, 176, 177].

Recommendations: Consider early splinting to reduce pain and blood loss and to facilitate transport (1C). Use splinting devices with which you are familiar (1C). Consider the use of vacuum splints (1C). Transport patients with multiple trauma using vacuum mattresses, rather than spine boards, to avoid additional soft tissue injury (1C).

\section{Analgesia}

Multiple trauma patients in the mountains should receive adequate analgesia. Analgesia decreases acute and long-term physiological and psychological responses to the stress of trauma $[178,179]$, increases comfort, and facilitates evacuation. Depending on training and licensure, mountain rescuers should be well versed in various modalities for pain reduction [178, 180]. Approaches to analgesia for trauma patients in the mountains vary widely amongst countries [178]. This is the result of differing professions and skill levels of medical providers, diverse laws and regulations, and large variations in transport times, especially with HEMS as opposed to ground rescue. 
Table 5 Benefits of reducing and immobilising a fracture, adapted from [14]

Reduced pain

Reduced blood loss

Minimised neurovascular complications

Reduced risk of fat embolism

Reduced risk of further tissue damage; facilitated healing

Easier transport

Nonpharmacologic interventions for acute pain in the mountains may include distraction and hypnosis. Most evidence is based on case reports. A recent metaanalysis demonstrated that distraction techniques, especially virtual reality and hypnosis, were moderately effective for pain relief in adults undergoing procedures for burn wound care [181]. Minor pain from trauma, is usually amenable to conservative treatment. Guidelines have been published by the Wilderness Medical Society for 'PRICE' therapy [180].

- Protect the injury (immobilise)

- Rest

- Ice (attenuates inflammation)

- Compression bandage

- Elevate the extremity

\section{Systemic analgesia}

Because opioids may worsen haemodynamics and depress ventilation, they should be used carefully. Judicious use of opioids may prevent untoward effects. Adverse effects can be reversed by naloxone. The use of ketamine and other medications, alone or with opioids, can prevent haemodynamic and respiratory decompensation (Table 6).

\section{Regional Anaesthesia}

Regional anaesthesia can be used in a mountain environment, especially to treat painful injuries during prolonged, difficult extrications (Table 7). Regional anaesthesia can decrease the need for systemic analgesia [195]. Regional anaesthesia involves special techniques. A practitioner must be fully aware of the indications, contraindications, and possible complications and should discuss the risks and possible benefits with the patient, if possible, before proceeding. Regional anaesthesia can prevent respiratory or haemodynamic compromise that commonly occurs with the use of systemic analgesia [196]. The amount of local anaesthetic may need to be decreased in elderly patients and in patients with liver or kidney disease [197]. Ultrasound guidance increases the success rate and can help to limit the dose of local anaesthetic.

\section{Recommendations: Consider nonpharmacologic in- terventions (1C).}

\section{Systemic analgesia}

Consider ketamine and other nonopioid analgesics (1C). Use opioids judiciously (1C).

\section{Regional anaesthesia}

Consider regional anaesthesia in the mountains, especially for painful injuries during prolonged, difficult extrications or during fracture and joint reduction (1B). Regional anaesthesia may be indicated to avoid haemodynamic or respiratory compromise associated with systemic analgesia (1B). Ultrasound guidance is recommended $(1 C)$.

\section{Hypothermia and temperature management}

Hypothermia is often associated with trauma [198, 199] and may increase mortality. For trauma patients, prevention of heat loss and rewarming can be critical. Prehospital recognition of hypothermia can be challenging. Clinical signs of hypothermia may be unreliable when there are coexisting conditions and when minimally invasive temperature measurement is not possible [200]. If a suitable thermometer is not available, core temperature can be estimated using the Swiss staging system [201]. The ideal prehospital thermometer should be easy to handle, accurate in all environmental conditions, and able to reflect small temperature changes rapidly. A good example is a thermistor-based tympanic probe designed for field use in cold environments (Table 8) [200]. The most accurate method of core temperature measurement is an oesophageal probe in the lower third of the oesophagus. This technique is only advisable when the airway has been secured.

A systematic review that assessed different types of insulation and active warming methods for use in a 'hypothermia wrap' concluded that there is a lack of prehospital randomised controlled trials with large sample sizes to provide strong recommendations regarding the most effective treatment in hypothermia [203]. It is not clear whether wet clothes should be removed before applying a tightly fitting vapour barrier [204, 205]. Wilderness Medical Society guidelines suggest cutting off wet clothing when a vapour barrier is not available or when the patient is at high risk of continued cooling [206]. The use of a vapour barrier, non-breathable waterproof material, to reduce evapourative and convective heat loss, is most effective when the vapour barrier, made of thick material or containing trapped air, (e.g. bubble wrap), is combined with thick insulating material [207209].

Sources of external heat include heat packs (electrical or chemical), hot water bottles, heat blankets 
Table 6 Systemic analgesics, adapted from [180]. LOE denotes level of evidence in parentheses, provided if available. COX cyclooxygenase, mcg micrograms, mg milligrams, g grams, kg kilograms, mL milliliters, IV intravenous, IM intramuscular IN intranasal, NSAIDS nonsteroidal anti-inflammatory drugs, OTFC: oral transmucosal fentanyl citrate, po: by mouth, q: 'every,' qd: daily, bid: twice daily, tid: three times daily

\begin{tabular}{|c|c|c|}
\hline $\begin{array}{l}\text { AGENT/DOSE } \\
\text { SITE }\end{array}$ & $\begin{array}{l}\text { DOSAGE ADULTS/(PEDS); } \\
\text { LOE }\end{array}$ & REMARKS \\
\hline Ice & $1 \mathrm{~B}$ & Simple, noninvasive; reduces inflammation/oedema; avoid freezing injury [180]. \\
\hline $\begin{array}{l}\text { NSAIDS/ } \\
\text { paracetamol }\end{array}$ & $1 \mathrm{~A}$ & $\begin{array}{l}\text { All NSAIDS: if po, potential dyspepsia lessened with food. Avoid with Gl bleed/ulcer history, } \\
\text { dehydration. Possible kidney injury or increased bleeding }\end{array}$ \\
\hline $\begin{array}{l}\text { Diclofenac } \\
\text { topical }\end{array}$ & $\begin{array}{l}2.3 \% \text { topical; } 2-4 \mathrm{~g} \text { bid; } \\
\text { unknown }\end{array}$ & \\
\hline Ibuprofen PO & $\begin{array}{l}2400 \mathrm{mg} / \mathrm{d} \text { divided tid }(10 \\
\mathrm{mg} / \mathrm{kg} / \mathrm{d}) ; 1 \mathrm{~A}\end{array}$ & \\
\hline Naproxen PO & $\begin{array}{l}660 \mathrm{mg} / \mathrm{d} \text { divided tid; } \\
\text { unknown }\end{array}$ & \\
\hline Meloxicam PO & 15 mg qd; unknown & $\begin{array}{l}\text { Cardiovascular events may increase. COX-2 selective inhibitor meloxicam minimises bleed/platelet } \\
\text { disfunction. }\end{array}$ \\
\hline Ketorolac IM & $\begin{array}{l}60 \mathrm{mg} \text { q } 6 \mathrm{~h}(0.5 \mathrm{mg} / \mathrm{kg} \\
\mathrm{q} 6 \mathrm{~h}) ; 2 \mathrm{C}\end{array}$ & \\
\hline IV & $\begin{array}{l}15-30 \mathrm{mg}(0.5 \mathrm{mg} / \mathrm{kg}, \max \\
15 \mathrm{mg}) ; 1 \mathrm{~B}\end{array}$ & \\
\hline Paracetamol PO & $\begin{array}{l}\text { Max } 1300 \mathrm{mg}(10 \mathrm{mg} / \mathrm{kg}) \\
\text { TID; } 1 \mathrm{~B}\end{array}$ & $\begin{array}{l}\text { Renal and GI sparing. Avoid in severe hepatic disease. Overdose can result in hepatic failure [179, } \\
\text { 180, 182].. NSAIDS + paracetamol result in pain diminution better than either alone. }\end{array}$ \\
\hline IV & $\begin{array}{l}>50 \mathrm{~kg}: 1 \mathrm{~g}<50 \mathrm{~kg}: 15 \mathrm{mg} / \\
\mathrm{kg} \mathrm{IV} / 15 \mathrm{~min} ; 1 \mathrm{~B}\end{array}$ & \\
\hline OPIOIDS & & $\begin{array}{l}\text { All opioids tend to cause respiratory depression/desaturation and arterial hypotension; monitor. } \\
\text { Avoid opioids if patient needs full cognition (i.e. self-evacuation). Naloxone reverses opioids [178- } \\
\text { 180]. }\end{array}$ \\
\hline Fentanyl IV & $\begin{array}{l}25-100 \mathrm{mcg}(1-3 \mathrm{mcg} / \mathrm{kg}) \\
1 \mathrm{~A}\end{array}$ & Slow fentanyl push mitigates risk of 'frozen chest.' \\
\hline IN & $180 \mathrm{mcg}(1.5 \mathrm{mcg} / \mathrm{kg}) ; 1 \mathrm{~B}$ & \\
\hline $\begin{array}{l}\text { Buccal/ } \\
\text { transmucosal }\end{array}$ & $\begin{array}{l}\text { OTFC: } 800 \mathrm{mcg}(10-15 \\
\mathrm{mcg} / \mathrm{kg}) ; 1 \mathrm{~B}\end{array}$ & $\begin{array}{l}\text { Oral transmucosal fentanyl citrate self-administered, ideal for austere situation. Transdermal route } \\
\text { good for sustained dosing. }\end{array}$ \\
\hline Transdermal & & Transdermal route good for sustained dosing. \\
\hline Morphine IV & $\begin{array}{l}5-10 \mathrm{mg}(0.1 \mathrm{mg} / \mathrm{kg}-\mathrm{max} 10 \\
\mathrm{mg}) ; 1 \mathrm{~A}\end{array}$ & Avoid morphine in renal failure. May cause histamine release. \\
\hline IM & $\begin{array}{l}10-20 \mathrm{mg}(0.2 \mathrm{mg} / \mathrm{kg} \text {, max } \\
10 \mathrm{mg}) ; 2 \mathrm{~B}\end{array}$ & Poor blood flow may limit absorption. \\
\hline Oxycodone PO & $5-10 \mathrm{mg}$ q8 h; 2B & PO opioids easy to carry on smaller expeditions. \\
\hline \multicolumn{3}{|l|}{ OTHER } \\
\hline Ketamine & $1 \mathrm{~B}$ & $\begin{array}{l}\text { Use half dose for S-ketamine. Slower administration lessens emesis and psychosis. Can cause hyper- } \\
\text { tension and tachycardia; preserves respiration; many prefer for multiple trauma. Vocal calming mea- } \\
\text { sures and adding midazolam minimise psychosis [178-185]. }\end{array}$ \\
\hline IV & $\begin{array}{l}10-30 \mathrm{mg}(0.1-0.3 \mathrm{mg} / \mathrm{kg}) \\
1 \mathrm{~B}\end{array}$ & \\
\hline IM & $1 \mathrm{mg} / \mathrm{kg} ; 2 \mathrm{C}$ & \\
\hline IN & $0.5 \mathrm{mg} / \mathrm{kg}(0.5 \mathrm{mg} / \mathrm{kg}) ; 2 \mathrm{~B}$ & \\
\hline $\begin{array}{l}\text { Methoxyflurane } \\
\text { Inhaled }\end{array}$ & $\begin{array}{l}3 \mathrm{~mL} \text { given to self; } \max 6 \\
\mathrm{~mL} / \mathrm{day} ; 2 \mathrm{~A}\end{array}$ & Altitude use. No renal effects; avoided by some; anxiolysis [186-188]. \\
\hline $\begin{array}{l}\text { Nitrous Oxide } \\
\text { nhaled }\end{array}$ & $60-70 \% \mathrm{~N}_{2} \mathrm{O} / 40-30 \% \mathrm{O}_{2} ; 2 \mathrm{~B}$ & Less effective at altitude, complex; potentiates barotrauma! \\
\hline
\end{tabular}


Table 7 Regional blocks appropriate for wilderness are listed below, adapted from [180], LOE denotes level of evidence

\begin{tabular}{|c|c|c|c|}
\hline Regional block & Indications & LOE & Remarks \\
\hline Intra-articular injection & Shoulder dislocation & $2 \mathrm{~B}$ & Not superior to procedural sedation [189] \\
\hline $\begin{array}{l}\text { Intrascalene nerve } \\
\text { block }\end{array}$ & Shoulder/arm injuries & $1 C$ & Phrenic nerve paralysis and respiratory compromise (not ideal for altitude) [190] \\
\hline $\begin{array}{l}\text { Supra- or infraclavicular } \\
\text { block }\end{array}$ & Pathology distal to shoulder & $1 \mathrm{~B}$ & Small ultrasound probe; $20-25 \mathrm{~mL}$ local anaesthetic, pneumothorax \\
\hline Axillary block & Pathology distal to shoulder & $1 C$ & Less anesthetic needed with ultrasound ( 15 mL) [191] \\
\hline $\begin{array}{l}\text { Median/ulnar/radial } \\
\text { block }\end{array}$ & Distal forearm/hand/multiple & $1 C$ & Nerves of mid-forearm readily seen with ultrasound; 3-5 mL [190] \\
\hline Intercostal nerve block & Isolated rib fracture(s) & $1 C$ & Ideal if cardiorespiratory status with systemic analgesia worrisome [192] \\
\hline Femoral nerve block & Femur fracture/pathology & $1 C$ & Not effective for posterior limb, or distal leg \\
\hline 3-in 1 block & Femur/knee or distal extremity & $1 C$ & $\begin{array}{l}\text { For thigh and distal extremity/foot; lateral femoral cutaneous- femoral and } \\
\text { obturator nerve }[191,193]\end{array}$ \\
\hline Fascia lliaca block & Femur fracture/pathology & $1 C$ & 90\% success rate prehospital, simple; less injury risk to nerves; $30 \mathrm{~mL}$ [194] \\
\hline Sciatic nerve block & $\begin{array}{l}\text { Posterior thigh/knee/distal lower } \\
\text { extremity }\end{array}$ & $1 C$ & With femoral and saphenous nerve block, good for knee and distal lesions [191] \\
\hline Ankle nerve block & Ankle/foot & $2 \mathrm{~B}$ & Need to block 5 nerves; high failure rate, good for isolated foot lacerations \\
\hline
\end{tabular}

(chemical or electrical), and forced warm air. External heat should be used to prevent heat loss and for rewarming when endogenous heat production is decreased, because shivering is impaired or absent. Shivering is suppressed or abolished in patients with moderate or severe hypothermia, and in patients multiple trauma, even if they are not hypothermic. The use of external heat sources in mildly hypothermic patients without trauma reduces peripheral cold stress and shivering [209]. External heat also decreases the cardiovascular and respiratory stress of shivering and increases thermal comfort. Overall, external heat is recommended. Heat transfer is most efficient when external heat is applied to the axillae, chest, and back [210]. Exothermic chemical heat packs should be used cautiously if combined with supplemental oxygen. Higher oxygen levels can intensify the heat production, potentially causing thermal burns [211]. Intravenous fluids should be warmed to $40^{\circ} \mathrm{C}$. Portable battery-powered intravenous fluid warmers are the most practical heating devices. Caution is warranted in selecting the device. Most devices currently on the market are incapable of heating adequate amounts of cold fluids to $40^{\circ} \mathrm{C}$ [212]. A temporary, warm microenvironment can

Table 8 Different sites for temperature measurement, advantages and disadvantages for field use [200]

\begin{tabular}{|c|c|c|c|c|c|}
\hline & Advantages & Disadvantages & $\begin{array}{l}\text { Suitability } \\
\text { for } \\
\text { prehospital } \\
\text { use }\end{array}$ & Logistic considerations & Field tested \\
\hline $\begin{array}{l}\text { Skin (heat } \\
\text { flux) }\end{array}$ & Noninvasive & $\begin{array}{l}\text { Low correlation with core } \\
\text { temperature }\end{array}$ & High & $\begin{array}{l}\text { Skin temperature affected by environment, } \\
\text { e.g. cold or wet }\end{array}$ & $\begin{array}{l}\text { Yes } \\
\text { (experimental } \\
\text { animal } \\
\text { model) }\end{array}$ \\
\hline Epitympanic & $\begin{array}{l}\text { Minimally } \\
\text { invasive. } \\
\text { Correlates with } \\
\text { brain } \\
\text { temperature }\end{array}$ & $\begin{array}{l}\text { Influenced by ambient temperature } \\
\text { and insulation of ear canal. Affected } \\
\text { if ear canal contains water or snow } \\
\text { [202]. }\end{array}$ & $\begin{array}{l}\text { Moderate- } \\
\text { high }\end{array}$ & $\begin{array}{l}\text { Insulation of the external auditory canal } \\
\text { improves the reliability of the reading. } \\
\text { Thermistor technology ideal; infrared } \\
\text { technology not reliable }\end{array}$ & Yes \\
\hline Rectum & $\begin{array}{l}\text { Commonly used } \\
\text { in hospital }\end{array}$ & $\begin{array}{l}\text { Lags behind core temperature when } \\
\text { rewarming }\end{array}$ & Moderate & $\begin{array}{l}\text { Needs to be inserted deeply }(>15 \mathrm{~cm}) \text { to } \\
\text { avoid measuring temperature of cold feces }\end{array}$ & Yes \\
\hline Bladder & $\begin{array}{l}\text { Allows to } \\
\text { monitor urinary } \\
\text { output }\end{array}$ & $\begin{array}{l}\text { Can be affected by cold diuresis. } \\
\text { Impractical for field use }\end{array}$ & Low & Mostly monitor based probes & No \\
\hline Oesophageal & $\begin{array}{l}\text { Best correlation } \\
\text { with core } \\
\text { temperature }\end{array}$ & $\begin{array}{l}\text { Requires an advanced airway in } \\
\text { place. Needs to be positioned in } \\
\text { lower third of oesophagus for } \\
\text { reliability }\end{array}$ & Moderate & $\begin{array}{l}\text { Mostly monitor based (only one hand-held } \\
\text { device) }\end{array}$ & Yes \\
\hline
\end{tabular}


be created by using a lightweight, rapidly deployed shelter. to decrease heat loss. Use of a warm environment also increases fine motor coordination for the rescuers.

Recommendations: If a suitable thermometer is not available, use the Swiss staging system to estimate core temperature (1C). Epitympanic thermometers using a thermistor are reliable for core temperature monitoring if they are designed for field use in cold environments. There is currently limited availability of suitable thermometers. (1B). In a patient with a secured airway consider core temperature measurement using an oesophageal probe (2A). A hypothermic patient should be extricated from the cold environment and covered by a vapour barrier and whole-body insulation (1C). Rewarming devices should be used in conjunction with vapour barriers and insulation (1C).

\section{Transport and hospital selection}

A patient with multiple trauma should be transported as rapidly as possible to a high-level trauma centre. Transport decisions for a patient with multiple trauma in the mountains should be coordinated with assertive management in the field and should be made early in order to ensure rapid, definitive in-hospital care. A helicopter should transport a medically qualified team and equipment to the scene [213]. During transport, continuous monitoring and uninterrupted treatment should be continued. A lightweight, stable stretcher should be used. The patient should not be moved in a vertical position, because this may cause hypotension especially in a patient with significant haemorrhage. Helicopters provide gentler and more stable transport than ground ambulances. Gentle transport is especially advantageous for a patient with a spinal injury or haemodynamic instability [214, 215]. Shorter transport times improve outcomes for trauma patients in shock. Air transport may improve survival compared with ground rescue in patients with TBI [216]. Patients with multiple trauma and TBI should be transported by air when this minimises the time to definitive care. With short distances, helicopter transport may not save time compared to ground ambulance transport and may not improve outcomes [217-219]. Helicopter transport may minimise prehospital time and the length of exposure to austere conditions compared to ground transport. However, in the mountains, availability of helicopter rescue may be limited by weather, low visibility, high altitude, and sometimes by other technical considerations. The potential benefits of air rescue should be carefully weighed against the risks. Helicopters may provide opportunities to reach distant trauma centres within a reasonable time, bypassing local smaller hospitals [220, 221]. In densely populated, highly developed areas, such as the European Alps, most locations are within a reasonable distance from a high-level trauma centre (i.e. 15-20 min flight time). This is usually not the case in less densely populated and less developed areas. The benefits of air rescue should be balanced against the inherent risks, especially when flight conditions may be hazardous.

Recommendations: Expedite transport (1C). Use a lightweight and stable stretcher(1C). Avoid moving a patient in a vertical position, as this may cause hypotension, especially with significant haemorrhage (1C). Use helicopter transport for a patient with spinal injury or haemodynamic instability (1C). Transport TBI patients by air if this saves time to definitive treatment (1B). Use a helicopter to reach a distant high-level trauma centre, bypassing smaller local hospitals (1B). Balance the benefits of air rescue with the inherent risks (1C).

\section{Ultrasound}

Point of care ultrasound (POCUS) is a key method for the initial assessment of patients with suspected trauma in the emergency department (Fig. 2) [222]. Trauma ultrasound (US) can be performed on helicopters [223] and in ambulances [224]. Ultrasound can be useful in trauma patients $[225,226]$, because it may help to guide treatment and the choice of destination hospital [227]. An operator should consider whether the results of POCUS are likely to change management. Use of POCUS should not delay arrival to hospital unless the results are critically important as a decision tool for initiating a lifesaving intervention. Improved survival with the use of POCUS has not yet been reported.

\section{Airway}

Ultrasound may be useful in managing a difficult airway to find cricothyrotomy landmarks or confirm tracheal intubation [228-230].

\section{Chest}

Prehospital lung ultrasound is highly sensitive for pneumothorax [225, 231]. In one study, $26 \%$ of chest decompressions performed by clinical criteria, could have been avoided [227]. Lung ultrasound can also be used to avoid thoracotomies in patients with traumatic circulatory arrest [232]. Ultrasound may also be useful to rule out pericardial effusion with tamponade [233-237] and pneumo- or haemothorax [238].

\section{Fractures}

In an austere environment, ultrasound performed by an experienced sonographer can accurately diagnose fractrures. POCUS might be used to prevent unnecessary evacuations for suspected extremity fractures that otherwise might need radiographic verification [239]. POCUS can also be used to diagnose pubic symphysis disruption 


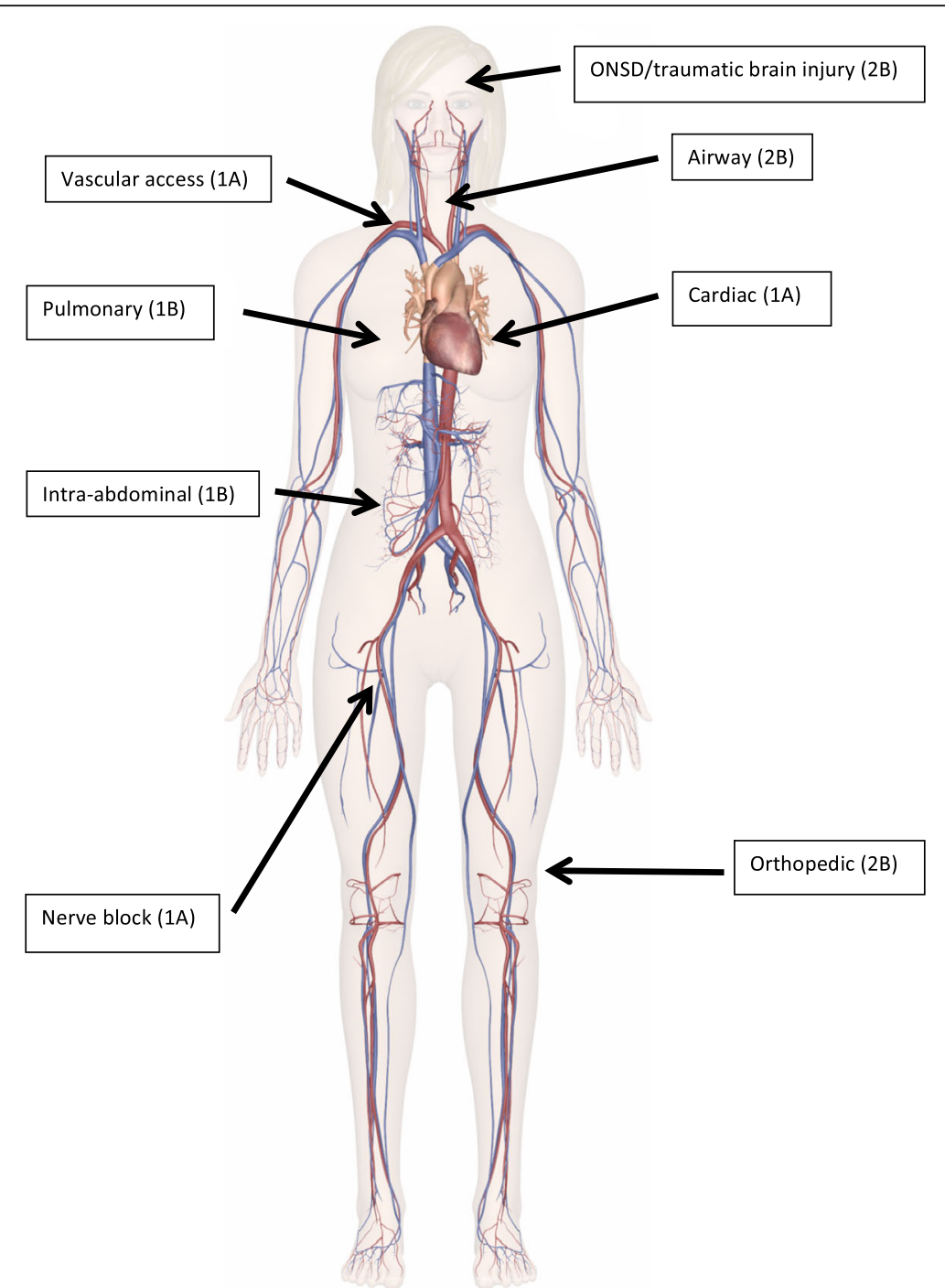

Fig. 2 Use of ultrasound in multiple trauma patients and grading of evidence. ONSD denotes optic nerve sheath diameter

or femur fractures [240], or to elucidate the cause of haemorrhagic shock.

\section{Traumatic brain injury}

Optic nerve sheath diameter can be measured with POCUS, correlating well with intracerebral pressure in TBI patients [241]. Thus, a pathologic increase of intracerebral pressure can be monitored with POCUS.

\section{Abdomen}

POCUS can be used to diagnose free fluid from severe blunt trauma to determine the choice of receiving hospital or to guide the diagnostic workup [242]. The Focused Assessment with Sonography for Trauma (FAST) may not be adequate to rule out internal haemorrhage in blunt abdominal trauma [222], but has a reasonable negative predictive value (94\%) [243]. FAST may be advantageous in selected cases, but does not improve survival [244], nor is FAST beneficial as part of a triage protocol in mass casualty incidents [245].

\section{Technical procedures}

POCUS can improve the safety and efficacy of invasive procedures, such as vascular catheterisation [246] and nerve blocks [247].

Recommendations: Consider using POCUS in patients with multiple trauma (2B), but do not delay arrival to hospital. Consider ultrasound to manage a difficult airway $(2 \mathrm{C})$, to detect pneumo- and haemothorax and pericardial effusion (1A), and to diagnose fractures (2B) and increased intracerebral pressure (2B). Consider performing a FAST exam on patients in shock (1B). Use 
POCUS for vascular access (1A) and nerve blocks (1A).

\section{Limitations}

Some limitations should be noted. Multiple trauma most often occurs in an urban setting. Most studies address this environment. In mountain areas, high quality evidence regarding treatment of multiple trauma is scarce. This discrepancy was also highlighted by a PubMed literature search on June 23rd 2020. Of 34,055 entries identified with the search term 'multiple trauma,' there were only 15 with the search term 'multiple trauma alpine.' We expanded the literature search by skimming the reference lists of the articles selected through the PubMed search. We cannot be sure that important studies were not missed with this approach.

A scoping review is not conducted as systematically or in as great a depth as a systematic review, although it still allows development of evidence-based recommendations through a rigorous and transparent approach. In this review, we focused on helicopter-supported mountain rescue missions, mostly because in many developed countries (e.g. Austria $>>98 \%$ ), as well as in some developing countries, the large majority of multiple trauma patients are rescued by HEMS. Some diagnostic and treatment options presented in this article may be mainly of academic interest (e.g. REBOA, regional anaesthesia, ultrasound). However, our intention was to present an up-to-date approach with all treatment options available worldwide and practiced in different prehospital systems. To date, some treatment options may only be used in a few highly specialized centres, but with technological progress the availability may spread quickly to other systems.

Because there is limited evidence, some of the recommendations rely mainly on expert opinion, at best supported by extrapolation of clinical data to prehospital care in mountain environments.

\section{Conclusions}

Management of patients with multiple trauma in mountain environments can be demanding. Safety of the rescuers and the victim has priority. Use of crABCDE with haemorrhage control first is critical. This should be followed by basic first aid, splinting, immobilisation, analgesia, and insulation. Duration of on-site medical treatment must be balanced against the need for rapid transfer to a trauma centre and should be as short as possible. Reduced on-scene times may be achieved with helicopter rescue. Advanced diagnostics, such as POCUS, may be beneficial. Treatment should be continued during transport.

\section{Supplementary Information}

The online version contains supplementary material available at https://doi. org/10.1186/s13049-020-00790-1.

Additional file 1.

Additional file 2.

Additional file 3.

Additional file 4.

\section{Abbreviations}

ABCDE: Airway, Breathing, Circulation, Disability, Exposure; AKI: Acute kidney injury; AVPU: Alert Voice Pain Unresponsive; ARDS: Adult respiratory distress syndrome; bid: twice daily; BP: Blood pressure; crABCDE: critical bleeding, Airway, Breathing Circulation, Disability, Exposure; CNS: Central nervous system; COX: cyclooxygenase; $\mathrm{ETCO}_{2}$ : End-tidal carbon dioxide;

FAST: Focused Assessment with Sonography for Trauma; G: Grams; GCS: Glasgow Coma Scale; HEMS: Helicopter emergency medical service; HES: Hydroxyethyl starch solution; ICAR: International Commission for Alpine Rescue; ICAR MedCom: International Commission for Mountain Emergency Medicine; ICU: Intensive care unit; IM: Intramuscular; IN: Intranasal; IO: intraosseous; ISS: Injury Severity Score; IV: Intravenous; KED: Kendrick Extrication Device; kg: Kilograms; LOE: Level of evidence; MA: Metabolic acidosis; MAP: Mean arterial pressure; mcg: Micrograms; mg: Milligrams; mL: Milliliters; mm Hg: Millimetres of mercury; $\mathrm{NaCl}$ : Sodium chloride; NEXUS: National Emergency X-radiography Utilization Study; NSAIDS: Nonsteroidal anti-inflammatory drugs; OTFC: Oral transmucosal fentanyl citrate;

PICO: Population Intervention Comparator Outcome; po: by mouth; POCUS: Point of Care Ultrasound; PRICE: Protect the injury, Rest, Ice, Compression, Elevation; qd: daily (dose); PRBCs: Packed red blood cells; REBOA: Resuscitative Balloon Occlusion of the Aorta; SMR: Spinal motion restriction; $\mathrm{SpO}_{2}$ : Oxygen saturation by pulse oximetry; SPB: Systolic blood pressure; TBI: Traumatic brain injury; tid: three times daily (dose); TXA: Tranexamic acid

\section{Acknowledgements}

The Department of Innovation and Research at the University of the Autonomous Province of Bozen/Bolzano, Italy for covering the Open Access publication costs.

\section{Authors' contributions}

PP conceptualized the study. All authors contributed, revised, read, and approved the final manuscript.

Funding

This article was funded solely by institutional resources.

\section{Competing interests}

The authors declare that they have no competing interests.

\section{Author details}

${ }^{1}$ Austrian Society of Mountain and High Altitude Medicine, Emergency physician, Austrian Mountain and Helicopter Rescue, Altach, Austria. ${ }^{2}$ Emergency Department Liège University Hospital, CMH HEMS Lead physician and medical director, Senior Lecturer at the University of Liège, Liège, Belgium. ${ }^{3}$ Mountain Emergency Paramedic, AHEMS, Canadian Society of Mountain Medicine, Whistler Blackcomb Ski Patrol, Whistler, Canada. ${ }^{4}$ Department of Emergency Medicine, University Hospital and University of Bern, Switzerland and Institute of Mountain Emergency Medicine, Eurac Research, Bolzano, Italy. ${ }^{5}$ Medical Officer Mountain Rescue England and Wales, Wales, UK. ${ }^{6}$ Department of Anaesthesiology, Intensive Care and Pain Medicine, Hospitallers Brothers Saint-Elisabeth-Hospital Straubing, Bavarian Mountain Rescue Service, Straubing, Germany. ${ }^{7}$ Adjunct Assistant Professor, Emergency Medicine, University of Maryland School of Medicine, Mountain Medicine Society of Nepal, Kathmandu, Nepal. ${ }^{8}$ ICAR MedCom, Department of Emergency Medicine, Stanford University Medical Center, Stanford, CA, USA. ${ }^{9}$ Alaska Native Medical Center, Anchorage, AK, USA. ${ }^{10}$ University Hospital Germans Trias i Pujol, Badalona, Spain. ${ }^{11}$ Department of Emergency Medicine, University of Colorado School of Medicine, Aurora, CO, USA.

${ }^{12}$ Department of Cardiovascular Medicine and Director of Mountain Medicine, Research, and Survey Division, Hokkaido Ohno Memorial Hospital, 
Sapporo, Japan. ${ }^{13}$ Emergency Department, Boulder Community Health, Boulder, CO, USA. ${ }^{14}$ Institute of Mountain Emergency Medicine, Eurac Research, Bolzano, Italy. ${ }^{15}$ The Corpo Nazionale Soccorso Alpino e Speleologico, National Medical School (CNSAS SNaMed), Milan, Italy. ${ }^{16}$ Department of Emergency Medicine, International Mountain Medicine Center, University of New Mexico, Albuquerque, NM, USA. ${ }^{17}$ Department of Anaesthesiology and Intensive Care Medicine, St. John of God Hospital, Paracelsus Medical University, Salzburg, Austria.

Received: 7 May 2020 Accepted: 10 September 2020 Published online: 14 December 2020

\section{References}

1. Rauch S, Dal Cappello T, Strapazzon G, Palma M, Bonsante F, Gruber E, Strohle M, Mair P, Brugger H. International Alpine trauma registry study G. pre-hospital times and clinical characteristics of severe trauma patients: a comparison between mountain and urban/suburban areas. Am J Emerg Med. 2018;36(10):1749-53.

2. Hearns S. The Scottish mountain rescue casualty study. Emerg Med J. 2003; 20(3):281-4

3. Gross T, Amsler F. Long-term outcome following multiple trauma in working age : a prospective study in a Swiss trauma center. Unfallchirurg. 2016;119(11):921-8.

4. Gross T, Attenberger C, Huegli RW, Amsler F. Factors associated with reduced longer-term capacity to work in patients after polytrauma: a Swiss trauma center experience. J Am Coll Surg. 2010;211(1):81-91.

5. Munn Z, Peters MDJ, Stern C, Tufanaru C, McArthur A, Aromataris E. Systematic review or scoping review? Guidance for authors when choosing between a systematic or scoping review approach. BMC Med Res Methodol. 2018:18(1):143.

6. Guyatt G, Gutterman D, Baumann MH, Addrizzo-Harris D, Hylek EM, Phillips B, Raskob G, Lewis SZ, Schunemann H. Grading strength of recommendations and quality of evidence in clinical guidelines: report from an american college of chest physicians task force. Chest. 2006;129(1):17481.

7. Rauch S, Wallner B, Strohle M, Dal Cappello T, Brodmann Maeder M. Climbing accidents-prospective data analysis from the international Alpine trauma registry and systematic review of the literature. Int J Environ Res Public Health. 2019;17(1)..

8. Strohle M, Beeretz I, Rugg C, Woyke S, Rauch S, Paal P. Canyoning accidents in Austria from 2005 to 2018. Int J Environ Res Public Health. 2019:17(1).

9. Ansari M, Nourian R, Khodaee M. Mountain Biking Injuries. Curr Sports Med Rep. 2017;16(6):404-12.

10. Strohle M, Woyke S, Wallner B, Brodmann Maeder M, Brugger H, Paal P. Aviation sports crashes in the Austrian Mountains: a 10-year retrospective study. Wilderness Environ Med. 2020;31(2):165-73.

11. Bigdon SF, Gewiess J, Hoppe S, Exadaktylos AK, Benneker LM, Fairhurst PG Albers CE. Spinal injury in alpine winter sports: a review. Scand J Trauma Resusc Emerg Med. 2019;27(1):69

12. Newgard CD, Schmicker RH, Hedges JR, Trickett JP, Davis DP, Bulger EM, Aufderheide TP, Minei JP, Hata JS, Gubler KD, et al. Emergency medical services intervals and survival in trauma: assessment of the "golden hour" in a north American prospective cohort. Ann Emerg Med. 2010;55(3):235-46 e234.

13. Newgard CD, Meier EN, Bulger EM, Buick J, Sheehan K, Lin S, Minei JP, Barnes-Mackey RA, Brasel K, Investigators ROC. Revisiting the "Golden hour": an evaluation of out-of-hospital time in shock and traumatic brain injury. Ann Emerg Med. 2015;66(1):30-41 41 e31-33.

14. Ellerton J, Tomazin I, Brugger H, Paal P, International Commission for Mountain Emergency M. Immobilization and splinting in mountain rescue. Official recommendations of the International Commission for Mountain Emergency Medicine, ICAR MedCom, intended for mountain rescue first responders, physicians, and rescue organizations. High Alt Med Biol. 2009; 10(4):337-42.

15. Hodgetts $T$ J, Mahoney PF, Russell $M Q$, Byers $M$. $A B C$ to $\angle C>A B C$ : redefining the military trauma paradigm. Emerg Med J. 2006;23(10):745-6.

16. EMS, Tactical Care and Evacuation Under Fire [https://www.ncbi.nlm.nih. gov/books/NBK441967/].

17. Baekgaard JS, Isbye D, Ottosen Cl, Larsen MH, Andersen JH, Rasmussen LS, Steinmetz J. Restrictive vs liberal oxygen for trauma patients-the TRAUMOX pilot randomised clinical trial. Acta Anaesthesiol Scand. 2019;63(7):947-55.
18. Lockey DJ, Healey B, Crewdson K, Chalk G, Weaver AE, Davies GE. Advanced airway management is necessary in prehospital trauma patients. $\mathrm{Br} J$ Anaesth. 2015;114(4):657-62.

19. Pietsch U, Knapp J, Kreuzer O, Ney L, Strapazzon G, Lischke V, Albrecht R, Phillips $\mathrm{P}$, Rauch $\mathrm{S}$. Advanced airway management in hoist and longline operations in mountain HEMS - considerations in austere environments: a narrative review this review is endorsed by the International Commission for Mountain Emergency Medicine (ICAR MedCom). Scand J Trauma Resusc Emerg Med. 2018;26(1):23.

20. Angerman $\mathrm{S}$, Kirves $\mathrm{H}$, Nurmi J. A before-and-after observational study of a protocol for use of the C-MAC videolaryngoscope with a Frova introducer in pre-hospital rapid sequence intubation. Anaesthesia. 2018; 73(3):348-55

21. Young B. The intubating laryngeal-mask airway may be an ideal device for airway control in the rural trauma patient. Am J Emerg Med. 2003; 21(1):80-5.

22. Tarpgaard M, Hansen TM, Rognas L. Anaesthetist-provided pre-hospital advanced airway management in children: a descriptive study. Scand J Trauma Resusc Emerg Med. 2015;23:61.

23. Hoffman JR, Wolfson AB, Todd K, Mower WR. Selective cervical spine radiography in blunt trauma: methodology of the National Emergency Xradiography utilization study (NEXUS). Ann Emerg Med. 1998;32(4):461-9.

24. Theodore N, Hadley MN, Aarabi B, Dhall SS, Gelb DE, Hurlbert RJ, Rozzelle CJ, Ryken TC, Walters BC. Prehospital cervical spinal immobilization after trauma. Neurosurgery. 2013;72(Suppl 2):22-34.

25. Sundstrom T, Asbjornsen H, Habiba S, Sunde GA, Wester K. Prehospital use of cervical collars in trauma patients: a critical review. J Neurotrauma. 2014; 31(6):531-40.

26. Paterek E, Isenberg DL, Schiffer $\mathrm{H}$. Characteristics of trauma patients with potential cervical spine injuries Underimmobilized by Prehospital providers. Spine (Phila Pa 1976). 2015;40(24):1898-902.

27. Velopulos CG, Shihab HM, Lottenberg L, Feinman M, Raja A, Salomone J, Haut ER. Prehospital spine immobilization/spinal motion restriction in penetrating trauma: a practice management guideline from the eastern Association for the Surgery of trauma (EAST). J Trauma Acute Care Surg. 2018;84(5):736-44.

28. Apfelbaum JD, Cantrill SV, Waldman N. Unstable cervical spine without spinal cord injury in penetrating neck trauma. Am J Emerg Med. 2000;18(1): $55-7$

29. Barkana Y, Stein M, Scope A, Maor R, Abramovich Y, Friedman Z, Knoller N. Prehospital stabilization of the cervical spine for penetrating injuries of the neck - is it necessary? Injury. 2000;31(5):305-9.

30. Garcia A, Liu TH, Victorino GP. Cost-utility analysis of prehospital spine immobilization recommendations for penetrating trauma. J Trauma Acute Care Surg. 2014;76(2):534-41.

31. Haut ER, Kalish BT, Efron DT, Haider AH, Stevens KA, Kieninger AN, Cornwell EE 3rd, Chang DC. Spine immobilization in penetrating trauma: more harm than good? J Trauma. 2010;68(1):115-20 discussion 120-111.

32. Klein Y, Arieli I, Sagiv S, Peleg K, Ben-Galim P. Cervical spine injuries in civilian victims of explosions: should cervical collars be used? J Trauma Acute Care Surg. 2016;80(6):985-8.

33. Hoffman JR, Mower WR, Wolfson AB, Todd KH, Zucker MI. Validity of a set of clinical criteria to rule out injury to the cervical spine in patients with blunt trauma. National Emergency X-radiography utilization study group. N Engl J Med. 2000;343(2):94-9

34. Domeier RM, Evans RW, Swor RA, Hancock JB, Fales W, Krohmer J, Frederiksen SM, Shork MA. The reliability of prehospital clinical evaluation for potential spinal injury is not affected by the mechanism of injury. Prehosp Emerg Care. 1999;3(4):332-7.

35. Stroh G, Braude D. Can an out-of-hospital cervical spine clearance protocol identify all patients with injuries? An argument for selective immobilization. Ann Emerg Med. 2001;37(6):609-15.

36. Vaillancourt C, Stiell IG, Beaudoin T, Maloney J, Anton AR, Bradford P, Cain E, Travers A, Stempien M, Lees M, et al. The out-of-hospital validation of the Canadian C-spine rule by paramedics. Ann Emerg Med. 2009;54(5):663-71 e661.

37. Slaar A, Fockens MM, Wang J, Maas M, Wilson DJ, Goslings JC, Schep NW, van Rijn RR. Triage tools for detecting cervical spine injury in pediatric trauma patients. Cochrane Database Syst Rev. 2017;12:CD011686.

38. Lee SL, Sena M, Greenholz SK, Fledderman M. A multidisciplinary approach to the development of a cervical spine clearance protocol: process, rationale, and initial results. J Pediatr Surg. 2003;38(3):358-62 discussion 358-362. 
39. Chan M, Al-Buali W, Charyk Stewart T, Singh RN, Kornecki A, Seabrook JA, Fraser DD. Cervical spine injuries and collar complications in severely injured paediatric trauma patients. Spinal Cord. 2013;51(5):360-4.

40. Viccellio P, Simon H, Pressman BD, Shah MN, Mower WR, Hoffman JR, Group N. A prospective multicenter study of cervical spine injury in children. Pediatrics. 2001;108(2):E20.

41. McGrath T, Murphy C. Comparison of a SAM splint-molded cervical collar with a Philadelphia cervical collar. Wilderness Environ Med. 2009; 20(2):166-8.

42. Kreinest M, Goller S, Rauch G, Frank C, Gliwitzky B, Wolfl CG, Matschke S, Munzberg M. Application of cervical collars - an analysis of practical skills of professional emergency Medical care providers. PLoS One. 2015;10(11): e0143409.

43. Davies G, Deakin C, Wilson A. The effect of a rigid collar on intracranial pressure. Injury. 1996;27(9):647-9.

44. Kolb JC, Summers RL, Galli RL. Cervical collar-induced changes in intracranial pressure. Am J Emerg Med. 1999:17(2):135-7.

45. Karason S, Reynisson K, Sigvaldason K, Sigurdsson GH. Evaluation of clinical efficacy and safety of cervical trauma collars: differences in immobilization, effect on jugular venous pressure and patient comfort. Scand J Trauma Resusc Emerg Med. 2014;22:37.

46. Stone MB, Tubridy CM, Curran $\mathrm{R}$. The effect of rigid cervical collars on internal jugular vein dimensions. Acad Emerg Med. 2010;17(1):100-2.

47. Woster CM, Zwank MD, Pasquarella JR, Wewerka SS, Anderson JP, Greupner JT, Motalib S. Placement of a cervical collar increases the optic nerve sheath diameter in healthy adults. Am J Emerg Med. 2018;36(3):430-4.

48. Stolmeijer R, Bouma HR, Zijlstra JG, Drost-de Klerck AM, Ter Maaten JC, Ligtenberg JJM. A systematic review of the effects of Hyperoxia in acutely ill patients: should we aim for less? Biomed Res Int. 2018;2018:7841295.

49. Helm M, Schuster R, Hauke J, Lampl L. Tight control of prehospital ventilation by capnography in major trauma victims. Br J Anaesth. 2003; 90(3):327-32.

50. Haider T, Halat G, Heinz T, Hajdu S, Negrin LL. Thoracic trauma and acute respiratory distress syndrome in polytraumatized patients: a retrospective analysis. Minerva Anestesiol. 2017;83(10):1026-33.

51. Helm M, Hauke J, Esser M, Lampl L, Bock KH. Diagnosis of blunt thoracic trauma in emergency care. Use of continuous pulse oximetry monitoring. Chirurg. 1997:68(6):606-12

52. Knotts D, Arthur AO, Holder P, Herrington T, Thomas SH. Pneumothorax volume expansion in helicopter emergency medical services transport. Air Med J. 2013;32(3):138-43.

53. Leigh-Smith $\mathrm{S}$, Harris T. Tension pneumothorax--time for a re-think? Emerg Med J. 2005:22(1):8-16

54. Lesperance RN, Carroll CM, Aden JK, Young JB, Nunez TC. Failure rate of Prehospital needle decompression for tension pneumothorax in trauma patients. Am Surg. 2018;84(11):1750-5.

55. Chan L, Reilly KM, Henderson C, Kahn F, Salluzzo RF. Complication rates of tube thoracostomy. Am J Emerg Med. 1997;15(4):368-70

56. Fang M, Liu G, Luo G, Wu T. Does pigtail catheters relieve pneumothorax?: a PRISMA-compliant systematic review and meta-analysis. Medicine (Baltimore). 2018:97(47):e13255.

57. Bauman ZM, Kulvatunyou N, Joseph B, Jain A, Friese RS, Gries L, O'Keeffe T, Tang AL, Vercruysse $G$, Rhee $P$. A prospective study of 7-year experience using percutaneous 14-French pigtail catheters for traumatic Hemothorax/ Hemopneumothorax at a Level-1 trauma center: size still does not matter. World J Surg. 2018;42(1):107-13.

58. Hyde J, Sykes T, Graham T. Reducing morbidity from chest drains. BMJ. 1997;314(7085):914-5.

59. Valdez C, Sarani B, Young H, Amdur R, Dunne J, Chawla LS. Timing of death after traumatic injury--a contemporary assessment of the temporal distribution of death. J Surg Res. 2016;200(2):604-9.

60. Kohli-Seth R, Neuman T, Sinha R, Bassily-Marcus A. Use of echocardiography and modalities of patient monitoring of trauma patients. Curr Opin Anaesthesiol. 2010;23(2):239-45.

61. Rossaint R, Bouillon B, Cerny V, Coats TJ, Duranteau J, Fernandez-Mondejar E, Filipescu D, Hunt BJ, Komadina R, Nardi G, et al. The European guideline on management of major bleeding and coagulopathy following trauma: fourth edition. Crit Care. 2016;20:100.

62. Bouillon B, Marzi I. The updated German "Polytrauma - guideline": an extensive literature evaluation and treatment recommendation for the care of the critically injured patient. Eur J Trauma Emerg Surg. 2018;44(Suppl 1):1.
63. Bulger EM, Snyder D, Schoelles K, Gotschall C, Dawson D, Lang E, Sanddal ND, Butler FK, Fallat M, Taillac P, et al. An evidence based prehospital guideline for external hemorrhage control: American College of Surgeons Committee on trauma. Prehosp Emerg Care. 2014;18(2):163-73.

64. Singletary EM, Charlton NP, Epstein JL, Ferguson JD, Jensen JL, MacPherson Al, Pellegrino JL, Smith WW, Swain JM, Lojero-Wheatley LF, et al. Part 15: first aid: 2015 American Heart Association and American red Cross guidelines update for first aid. Circulation. 2015;132(18 Suppl 2):S574-89.

65. Spahn DR, Bouillon B, Cerny V, Duranteau J, Filipescu D, Hunt BJ, Komadina R, Maegele M, Nardi G, Riddez L, et al. The European guideline on management of major bleeding and coagulopathy following trauma: fifth edition. Crit Care. 2019;23(1):98.

66. Chang R, Eastridge BJ, Holcomb JB. Remote damage control resuscitation in austere environments. Wilderness Environ Med. 2017;28(2S):S124-34.

67. Kragh JF Jr, Dubick MA. Bleeding control with limb tourniquet use in the Wilderness setting: review of science. Wilderness Environ Med. 2017;28(2S): S25-32.

68. Scerbo MH, Holcomb JB, Taub E, Gates K, Love JD, Wade CE, Cotton BA. The trauma center is too late: major limb trauma without a pre-hospital tourniquet has increased death from hemorrhagic shock. J Trauma Acute Care Surg. 2017:83(6):1165-72.

69. Inaba K, Siboni S, Resnick S, Zhu J, Wong MD, Haltmeier T, Benjamin E, Demetriades D. Tourniquet use for civilian extremity trauma. J Trauma Acute Care Surg. 2015;79(2):232-7 quiz 332-233.

70. Dayan L, Zinmann C, Stahl S, Norman D. Complications associated with prolonged tourniquet application on the battlefield. Mil Med. 2008;173(1): 63-6.

71. Warriner Z, Lam L, Matsushima K, Benjamin E, Strumwasser A, Demetriades $D$, Inaba K. Initial evaluation of the efficacy and safety of in-hospital expandable hemostatic minisponge use in penetrating trauma. J Trauma Acute Care Surg. 2019;86(3):424-30

72. Smith S, White J, Wanis KN, Beckett A, McAlister VC, Hilsden R. The effectiveness of junctional tourniquets: a systematic review and metaanalysis. J Trauma Acute Care Surg. 2019:86(3):532-9.

73. van der Burg BLS B, van Dongen T, Morrison JJ, Hedeman Joosten PPA, DuBose JJ, Horer TM, Hoencamp R. A systematic review and meta-analysis of the use of resuscitative endovascular balloon occlusion of the aorta in the management of major exsanguination. Eur J Trauma Emerg Surg. 2018; 44(4):535-50.

74. Davidson AJ, Russo RM, Reva VA, Brenner ML, Moore LJ, Ball C, Bulger E, Fox CJ, DuBose JJ, Moore EE, et al. The pitfalls of resuscitative endovascular balloon occlusion of the aorta: risk factors and mitigation strategies. J Trauma Acute Care Surg. 2018;84(1):192-202.

75. Vermeulen $B$, Peter R, Hoffmeyer P, Unger PF. Prehospital stabilization of pelvic dislocations: a new strap belt to provide temporary hemodynamic stabilization. Swiss Surg. 1999;5(2):43-6.

76. Qureshi A, McGee A, Cooper JP, Porter KM. Reduction of the posterior pelvic ring by non-invasive stabilisation: a report of two cases. Emerg Med J. 2005;22(12):885-6.

77. Bakhshayesh P, Boutefnouchet T, Totterman A. Effectiveness of non invasive external pelvic compression: a systematic review of the literature. Scand J Trauma Resusc Emerg Med. 2016;24:73.

78. Hoch A, Zeidler S, Pieroh P, Josten C, Stuby FM, Herath SC. German pelvic trauma R: trends and efficacy of external emergency stabilization of pelvic ring fractures: results from the German pelvic trauma registry. Eur J Trauma Emerg Surg. 2019.

79. Collaborators C-t, Shakur H, Roberts I, Bautista R, Caballero J, Coats T, Dewan Y, El-Sayed H, Gogichaishvili T, Gupta S, et al. Effects of tranexamic acid on death, vascular occlusive events, and blood transfusion in trauma patients with significant haemorrhage (CRASH-2): a randomised, placebo-controlled trial. Lancet. 2010;376(9734):23-32.

80. Roberts I, Shakur H, Ker K, Coats T, Collaborators C-T. Antifibrinolytic drugs for acute traumatic injury. Cochrane Database Syst Rev. 2012;12:CD004896

81. Roberts I, Prieto-Merino D, Manno D. Mechanism of action of tranexamic acid in bleeding trauma patients: an exploratory analysis of data from the CRASH-2 trial. Crit Care. 2014;18(6):685.

82. Roberts I, Coats T, Edwards P, Gilmore I, Jairath V, Ker K, Manno D, Shakur H, Stanworth S, Veitch A. HALT-IT--tranexamic acid for the treatment of gastrointestinal bleeding: study protocol for a randomised controlled trial. Trials. 2014:15:450 
83. Huebner BR, Dorlac WC, Cribari C. Tranexamic acid use in Prehospital uncontrolled hemorrhage. Wilderness Environ Med. 2017;28(2S):S50-60.

84. Wafaisade A, Lefering R, Bouillon B, Bohmer AB, Gassler M, Ruppert M, TraumaRegister DGU. Prehospital administration of tranexamic acid in trauma patients. Crit Care. 2016;20(1):143.

85. Cole E, Davenport R, Willett K, Brohi K. Tranexamic acid use in severely injured civilian patients and the effects on outcomes: a prospective cohort study. Ann Surg. 2015;261(2):390-4.

86. Reiter RA, Mayr F, Blazicek H, Galehr E, Jilma-Stohlawetz P, Domanovits H, Jilma B. Desmopressin antagonizes the in vitro platelet dysfunction induced by GPIIb/Illa inhibitors and aspirin. Blood. 2003;102(13):4594-9.

87. Leithauser B, Zielske D, Seyfert UT, Jung F. Effects of desmopressin on platelet membrane glycoproteins and platelet aggregation in volunteers on clopidogrel. Clin Hemorheol Microcirc. 2008;39(1-4):293-302.

88. Laupacis A, Fergusson D. Drugs to minimize perioperative blood loss in cardiac surgery: meta-analyses using perioperative blood transfusion as the outcome. The international study of Peri-operative transfusion (ISPOT) Investigators. Anesth Analg. 1997;85(6):1258-67.

89. McMillian WD, Rogers FB. Management of prehospital antiplatelet and anticoagulant therapy in traumatic head injury: a review. J Trauma. 2009; 66(3):942-50.

90. Powner DJ, Hartwell EA, Hoots WK. Counteracting the effects of anticoagulants and antiplatelet agents during neurosurgical emergencies. Neurosurgery. 2005;57(5):823-31 discussion 823-831.

91. Kapapa T, Rohrer S, Struve S, Petscher M, Konig R, Wirtz CR, Woischneck D. Desmopressin acetate in intracranial haemorrhage. Neurol Res Int. 2014; 2014:298767.

92. Levine M, Swenson S, McCormick T, Henderson SO, Thomas SH, Markland FS. Reversal of thienopyridine-induced platelet dysfunction following desmopressin administration. J Med Toxicol. 2013;9(2):139-43.

93. Teng R, Mitchell PD, Butler $K$. The effect of desmopressin on bleeding time and platelet aggregation in healthy volunteers administered ticagrelor. J Clin Pharm Ther. 2014;39(2):186-91.

94. Castaman G, Linari S. Diagnosis and treatment of von Willebrand disease and rare bleeding disorders. J Clin Med. 2017;6(4).

95. Coppola A, Di Minno G. Desmopressin in inherited disorders of platelet function. Haemophilia. 2008;14(Suppl 1):31-9.

96. Ng KF, Cheung CW, Lee $Y$, Leung SW. Low-dose desmopressin improves hypothermia-induced impairment of primary haemostasis in healthy volunteers. Anaesthesia. 2011;66(11):999-1005.

97. Hanke AA, Dellweg C, Kienbaum P, Weber CF, Gorlinger K, Rahe-Meyer N. Effects of desmopressin on platelet function under conditions of hypothermia and acidosis: an in vitro study using multiple electrode aggregometry*. Anaesthesia. 2010;65(7):688-91.

98. Crescenzi G, Landoni G, Biondi-Zoccai G, Pappalardo F, Nuzzi M, Bignami E, Fochi O, Maj G, Calabro MG, Ranucci M, et al. Desmopressin reduces transfusion needs after surgery: a meta-analysis of randomized clinical trials. Anesthesiology. 2008;109(6):1063-76.

99. Yamamoto K, Yamaguchi A, Sawano M, Matsuda M, Anan M, Inokuchi K, Sugiyama S. Pre-emptive administration of fibrinogen concentrate contributes to improved prognosis in patients with severe trauma. Trauma Surg Acute Care Open. 2016;1 (1):e000037.

100. Innerhofer $P$, Fries $D$, Mittermayr $M$, Innerhofer $N$, von Langen $D$, Hell $T$, Gruber G, Schmid S, Friesenecker B, Lorenz IH, et al. Reversal of traumainduced coagulopathy using first-line coagulation factor concentrates or fresh frozen plasma (RETIC): a single-Centre, parallel-group, open-label, randomised trial. Lancet Haematol. 2017;4(6):e258-71.

101. Matsushima K, Benjamin E, Demetriades D. Prothrombin complex concentrate in trauma patients. Am J Surg. 2015;209(2):413-7.

102. Berger K, Santibanez M, Lin L, Lesch CA. A low-dose 4F-PCC protocol for DOAC-associated intracranial hemorrhage. J Intensive Care Med. 2019: 885066619840992

103. Sarode R, Milling TJ Jr, Refaai MA, Mangione A, Schneider A, Durn BL, Goldstein $J N$. Efficacy and safety of a 4-factor prothrombin complex concentrate in patients on vitamin $\mathrm{K}$ antagonists presenting with major bleeding: a randomized, plasmacontrolled, phase IIIb study. Circulation. 2013;128(11):1234-43.

104. Goldstein JN, Refaai MA, Milling TJ Jr, Lewis B, Goldberg-Alberts R, Hug BA, Sarode R. Four-factor prothrombin complex concentrate versus plasma for rapid vitamin $\mathrm{K}$ antagonist reversal in patients needing urgent surgical or invasive interventions: a phase 3b, open-label, non-inferiority, randomised trial. Lancet. 2015;385(9982):2077-87.
105. Bennett BL. Bleeding control using hemostatic dressings: lessons learned. Wilderness Environ Med. 2017;28(2S):S39-49.

106. Kozen BG, Kircher SJ, Henao J, Godinez FS, Johnson AS. An alternative hemostatic dressing: comparison of CELOX, HemCon, and QuikClot. Acad Emerg Med. 2008;15(1):74-81.

107. Allison HA. Hemorrhage control: lessons learned from the battlefield use of hemostatic agents that can be applied in a hospital setting. Crit Care Nurs Q. 2019;42(2):165-72.

108. Peters JH, Smulders PSH, Moors XRJ, Bouman SJM, Meijs C, Hoogerwerf N, Edwards MJR. Are on-scene blood transfusions by a helicopter emergency medical service useful and safe? A multicentre case-control study. Eur J Emerg Med. 2019;26(2):128-32.

109. Sato Folatre JG, Arnell P, Henning M, Josefsson K, Skallsjo G, Ricksten SE. Introduction of prehospital blood transfusion programme in Sweden: experiences from a physician staffed helicopter emergency medical service. Lakartidningen. 2018;115.

110. Krook C, O'Dochartaigh D, Martin D, Piggott Z, Deedo R, Painter S, van Werkhoven G, McKay D, Nesdoly D, Armstrong JN. Blood on board: the development of a prehospital blood transfusion program in a Canadian helicopter emergency medical service. CJEM. 2019;21(3):365-73.

111. Moors XRJ, Bouman SJM, Peters JH, Smulders P, Alink MBO, Hartog DD, Stolker RJ. Prehospital blood transfusions in pediatric patients by a helicopter emergency Medical service. Air Med J. 2018;37(5):321-4.

112. Gurney JM, Spinella PC. Blood transfusion management in the severely bleeding military patient. Curr Opin Anaesthesiol. 2018;31(2):207-14.

113. Semler MW, Self WH, Wanderer JP, Ehrenfeld JM, Wang L, Byrne DW, Stollings JL, Kumar AB, Hughes CG, Hernandez A, et al. Balanced Crystalloids versus saline in critically ill adults. N Engl J Med. 2018;378(9):829-39.

114. Sarrafzadeh AS, Peltonen EE, Kaisers U, Kuchler I, Lanksch WR, Unterberg AW. Secondary insults in severe head injury--do multiply injured patients do worse? Crit Care Med. 2001;29(6):1116-23.

115. Chesnut RM, Marshall LF, Klauber MR, Blunt BA, Baldwin N, Eisenberg HM Jane JA, Marmarou A, Foulkes MA. The role of secondary brain injury in determining outcome from severe head injury. J Trauma. 1993;34(2):216-22.

116. Karamanos E, Talving P, Skiada D, Osby M, Inaba K, Lam L, Albuz O, Demetriades D. Is prehospital endotracheal intubation associated with improved outcomes in isolated severe head injury? A matched cohort analysis. Prehosp Disaster Med. 2014;29(1):32-6.

117. Bossers SM, Schwarte LA, Loer SA, Twisk JW, Boer C, Schober P. Experience in Prehospital endotracheal intubation significantly influences mortality of patients with severe traumatic brain injury: a systematic review and metaanalysis. PLoS One. 2015;10(10):e0141034.

118. Haltmeier T, Benjamin E, Siboni S, Dilektasli E, Inaba K, Demetriades D. Prehospital intubation for isolated severe blunt traumatic brain injury: worse outcomes and higher mortality. Eur J Trauma Emerg Surg. 2017;43(6):731-9.

119. Davis DP, Peay J, Sise MJ, Vilke GM, Kennedy F, Eastman AB, Velky T, Hoyt $D B$. The impact of prehospital endotracheal intubation on outcome in moderate to severe traumatic brain injury. J Trauma. 2005;58(5):933-9.

120. Wang HE, Brown SP, MacDonald RD, Dowling SK, Lin S, Davis D, Schreiber MA, Powell J, van Heest R, Daya M. Association of out-of-hospital advanced airway management with outcomes after traumatic brain injury and hemorrhagic shock in the ROC hypertonic saline trial. Emerg Med J. 2014; 31(3):186-91.

121. Bulger EM, Copass MK, Sabath DR, Maier RV, Jurkovich GJ. The use of neuromuscular blocking agents to facilitate prehospital intubation does not impair outcome after traumatic brain injury. J Trauma. 2005;58(4):718-23 discussion 723-714

122. Seo DE, Shin SD, Song KJ, Ro YS, Hong KJ, Park JH. Effect of hypoxia on mortality and disability in traumatic brain injury according to shock status: a cross-sectional analysis. Am J Emerg Med. 2019;37(9):1709-15.

123. Warner KJ, Cuschieri J, Copass MK, Jurkovich GJ, Bulger EM. The impact of prehospital ventilation on outcome after severe traumatic brain injury. J Trauma. 2007;62(6):1330-6 discussion 1336-1338

124. Helm M, Hauke J, Lampl L. A prospective study of the quality of pre-hospital emergency ventilation in patients with severe head injury. Br J Anaesth. 2002;88(3):345-9.

125. Hill DA, Abraham KJ, West RH. Factors affecting outcome in the resuscitation of severely injured patients. Aust N Z J Surg. 1993:63(8): 604-9.

126. Butcher I, Maas Al, Lu J, Marmarou A, Murray GD, Mushkudiani NA, McHugh GS, Steyerberg EW. Prognostic value of admission blood pressure in 
traumatic brain injury: results from the IMPACT study. J Neurotrauma. 2007; 24(2):294-302.

127. Berry C, Ley EJ, Bukur M, Malinoski D, Margulies DR, Mirocha J, Salim A. Redefining hypotension in traumatic brain injury. Injury. 2012;43(11):1833-7.

128. Spaite DW, Hu C, Bobrow BJ, Chikani V, Barnhart B, Gaither JB, Denninghoff KR, Adelson PD, Keim SM, Viscusi C, et al. Association of out-of-Hospital Hypotension Depth and Duration with Traumatic Brain Injury Mortality. Ann Emerg Med. 2017;70(4):522-30 e521.

129. Eastridge BJ, Salinas J, McManus JG, Blackburn L, Bugler EM, Cooke WH, Convertino VA, Wade CE, Holcomb JB. Hypotension begins at $110 \mathrm{~mm}$ hg: redefining "hypotension" with data. J Trauma. 2007;63(2):291-7 discussion 297-299.

130. Carney N, Totten AM, O'Reilly C, Ullman JS, Hawryluk GW, Bell MJ, Bratton SL, Chesnut R, Harris OA, Kissoon N, et al. Guidelines for the Management of Severe Traumatic Brain Injury. Fourth Edition Neurosurgery. 2017;80(1):6-15.

131. Brenner M, Stein DM, Hu PF, Aarabi B, Sheth K, Scalea TM. Traditional systolic blood pressure targets underestimate hypotension-induced secondary brain injury. J Trauma Acute Care Surg. 2012;72(5):1135-9.

132. Kannan N, Wang J, Mink RB, Wainwright MS, Groner Jl, Bell MJ, Giza CC, Zatzick DF, Ellenbogen RG, Boyle LN, et al. Timely hemodynamic resuscitation and outcomes in severe pediatric traumatic brain injury: preliminary findings. Pediatr Emerg Care. 2018;34(5):325-9.

133. Cooper DJ, Myles PS, McDermott FT, Murray LJ, Laidlaw J, Cooper G, Tremayne AB, Bernard SS, Ponsford J, Investigators HTSS. Prehospital hypertonic saline resuscitation of patients with hypotension and severe traumatic brain injury: a randomized controlled trial. JAMA. 2004;291(11): 1350-7.

134. Sumann G, Paal P, Mair P, Ellerton J, Dahlberg T, Zen-Ruffinen G, Zafren K, Brugger $\mathrm{H}$. Fluid management in traumatic shock: a practical approach for mountain rescue. Official recommendations of the International Commission for Mountain Emergency Medicine (ICAR MedCom). High Alt Med Biol. 2009;10(1):71-5.

135. Hylands M, Toma A, Beaudoin N, Frenette AJ, D'Aragon F, Belley-Cote E, Charbonney E, Moller MH, Laake JH, Vandvik PO, et al. Early vasopressor use following traumatic injury: a systematic review. BMJ Open. 2017;7(11): e017559.

136. Rickard AC, Smith JE, Newell P, Bailey A, Kehoe A, Mann C. Salt or sugar for your injured brain? A meta-analysis of randomised controlled trials of mannitol versus hypertonic sodium solutions to manage raised intracranial pressure in traumatic brain injury. Emerg Med J. 2014;31(8): 679-83.

137. Sakellaridis N, Pavlou E, Karatzas S, Chroni D, Vlachos K, Chatzopoulos K, Dimopoulou E, Kelesis C, Karaouli V. Comparison of mannitol and hypertonic saline in the treatment of severe brain injuries. J Neurosurg. 2011;114(2):545-8.

138. Wakai A, Roberts I, Schierhout G. Mannitol for acute traumatic brain injury. Cochrane Database Syst Rev. 2007;1:CD001049.

139. Wang $K$, Sun $M$, Jiang $H$, Cao XP, Zeng J. Mannitol cannot reduce the mortality on acute severe traumatic brain injury (TBI) patients: a metaanalyses and systematic review. Burns Trauma. 2015;3:8.

140. Agbeko RS, Pearson S, Peters MJ, McNames J, Goldstein B. Intracranial pressure and cerebral perfusion pressure responses to head elevation changes in pediatric traumatic brain injury. Pediatr Crit Care Med. 2012; 13(1):e39-47.

141. Alarcon JD, Rubiano AM, Okonkwo DO, Alarcon J, Martinez-Zapata MJ, Urrutia G, Bonfill Cosp X. Elevation of the head during intensive care management in people with severe traumatic brain injury. Cochrane Database Syst Rev. 2017;12:CD009986.

142. Collaborators C-t. Effects of tranexamic acid on death, disability, vascular occlusive events and other morbidities in patients with acute traumatic brain injury (CRASH-3): a randomised, placebo-controlled trial. Lancet. 2019; 394(10210):1713-23.

143. Weng S, Wang W, Wei Q, Lan H, Su J, Xu Y. Effect of Tranexamic acid in patients with traumatic brain injury: a systematic review and meta-analysis. World Neurosurg. 2019;123:128-35.

144. Harris T, Davenport R, Hurst T, Jones J. Improving outcome in severe trauma: trauma systems and initial management: intubation, ventilation and resuscitation. Postgrad Med J. 2012;88(1044):588-94.
145. Jeremitsky E, Omert L, Dunham CM, Protetch J, Rodriguez A. Harbingers of poor outcome the day after severe brain injury: hypothermia, hypoxia, and hypoperfusion. J Trauma. 2003;54(2):312-9.

146. Lewis SR, Evans DJ, Butler AR, Schofield-Robinson OJ, Alderson P. Hypothermia for traumatic brain injury. Cochrane Database Syst Rev. 2017;9: CD001048.

147. Cooper DJ, Nichol AD, Bailey M, Bernard S, Cameron PA, Pili-Floury S, Forbes A, Gantner D, Higgins AM, Huet O, et al. Effect of early sustained prophylactic hypothermia on neurologic outcomes among patients with severe traumatic brain injury: the POLAR randomized clinical trial. JAMA. 2018;320(21):2211-20

148. Clifton GL, Valadka A, Zygun D, Coffey CS, Drever P, Fourwinds S, Janis LS, Wilde $E$, Taylor $P$, Harshman $K$, et al. Very early hypothermia induction in patients with severe brain injury (the National Acute Brain Injury Study: hypothermia II): a randomised trial. Lancet Neurol. 2011;10(2):131-9.

149. Kwan I, Bunn F, Roberts I. Spinal immobilisation for trauma patients. Cochrane Database Syst Rev. 2001;2:CD002803.

150. Hauswald M, Ong G, Tandberg D, Omar Z. Out-of-hospital spinal immobilization: its effect on neurologic injury. Acad Emerg Med. 1998;5(3): 214-9.

151. Hyldmo PK, Vist GE, Feyling AC, Rognas L, Magnusson V, Sandberg M, Soreide $E$. Is the supine position associated with loss of airway patency in unconscious trauma patients? A systematic review and meta-analysis. Scand J Trauma Resusc Emerg Med. 2015;23:50.

152. Kwan I, Bunn F. Effects of prehospital spinal immobilization: a systematic review of randomized trials on healthy subjects. Prehosp Disaster Med. 2005;20(1):47-53.

153. Quinn R, Williams J, Bennett B, Stiller G, Islas A, McCord S, Wilderness Medical S. Wilderness Medical society practice guidelines for spine immobilization in the austere environment. Wilderness Environ Med. 2013; 24(3):241-52.

154. Kornhall DK, Jorgensen JJ, Brommeland T, Hyldmo PK, Asbjornsen H, Dolven T, Hansen T, Jeppesen E. The Norwegian guidelines for the prehospital management of adult trauma patients with potential spinal injury. Scand J Trauma Resusc Emerg Med. 2017;25(1):2.

155. Todd NV, Skinner D, Wilson-MacDonald J. Secondary neurological deterioration in traumatic spinal injury: data from medicolegal cases. Bone Joint J. 2015:97-B(4):527-31.

156. Boissy P, Shrier I, Briere S, Mellete J, Fecteau L, Matheson GO, Garza D, Meeuwisse WH, Segal E, Boulay J, et al. Effectiveness of cervical spine stabilization techniques. Clin J Sport Med. 2011;21(2):80-8.

157. Raphael JH, Chotai R. Effects of the cervical collar on cerebrospinal fluid pressure. Anaesthesia. 1994;49(5):437-9.

158. Bruijns SR, Guly HR, Wallis LA. Effect of spinal immobilization on heart rate, blood pressure and respiratory rate. Prehosp Disaster Med. 2013;28(3):210-4.

159. Holla M. Value of a rigid collar in addition to head blocks: a proof of principle study. Emerg Med J. 2012;29(2):104-7.

160. Conrad BP, Horodyski M, Wright J, Ruetz P, Rechtine GR 2nd. Log-rolling technique producing unacceptable motion during body position changes in patients with traumatic spinal cord injury. J Neurosurg Spine. 2007;6(6): 540-3.

161. Mahshidfar B, Mofidi M, Yari AR, Mehrsorosh S. Long backboard versus vacuum mattress splint to immobilize whole spine in trauma victims in the field: a randomized clinical trial. Prehosp Disaster Med. 2013;28(5):462-5.

162. Luscombe MD, Williams JL. Comparison of a long spinal board and vacuum mattress for spinal immobilisation. Emerg Med J. 2003;20(5):476-8.

163. Hamilton RS, Pons PT. The efficacy and comfort of full-body vacuum splints for cervical-spine immobilization. J Emerg Med. 1996;14(5):553-9.

164. McDonald N, Webster M, Orkin A, VanderBurgh D, Johnson DE. The long backboard vs the vacuum mattress. Prehosp Disaster Med. 2014;29(1):110.

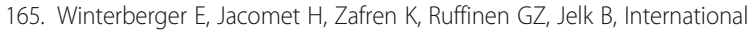
Commission for Mountain Emergency M, Terrestrial Rescue Commission of the International Commission for Alpine R. The use of extrication devices in crevasse accidents: official statement of the International Commission for Mountain Emergency Medicine and the terrestrial Rescue Commission of the International Commission for Alpine rescue intended for physicians, paramedics, and mountain rescuers. Wilderness Environ Med. 2008;19(2): $108-10$

166. Vayer JS, Hagmann JH, Llewellyn CH. Refining prehospital physical assessment skills: a new teaching technique. Ann Emerg Med. 1994;23(4): 786-90. 
167. Butler FK, Bennett B, Wedmore Cl. Tactical combat casualty care and Wilderness medicine: advancing trauma Care in Austere Environments. Emerg Med Clin North Am. 2017;35(2):391-407.

168. Wolberg AS, Meng ZH, Monroe DM 3rd, Hoffman M. A systematic evaluation of the effect of temperature on coagulation enzyme activity and platelet function. J Trauma. 2004;56(6):1221-8.

169. Beal AL, Ahrendt MN, Irwin ED, Lyng JW, Turner SV, Beal CA, Byrnes MT, Beilman GA. Prediction of blunt traumatic injuries and hospital admission based on history and physical exam. World J Emerg Surg. 2016;11(1):46.

170. Esmer E, Derst P, Lefering R, Schulz M, Siekmann H, Delank KS, das TraumaRegister DGU. Prehospital assessment of injury type and severity in severely injured patients by emergency physicians : an analysis of the TraumaRegister DGU(R). Unfallchirurg. 2017;120(5):409-16.

171. Mclntosh SE, Leemon D, Visitacion J, Schimelpfenig T, Fosnocht D. Medical incidents and evacuations on wilderness expeditions. Wilderness Environ Med. 2007;18(4):298-304

172. Lee C, Porter KM. Prehospital management of lower limb fractures. Emerg Med J. 2005;22(9):660-3.

173. Agrawal Y, Karwa J, Shah N, Clayson A. Traction splint: to use or not to use. J Perioper Pract. 2009;19(9):295-8.

174. Wood SP, Vrahas M, Wedel SK. Femur fracture immobilization with traction splints in multisystem trauma patients. Prehosp Emerg Care. 2003;7(2):241-3.

175. Abarbanell NR. Prehospital midthigh trauma and traction splint use: recommendations for treatment protocols. Am J Emerg Med. 2001;19(2):137-40.

176. Quinn RH, Macias DJ. The management of open fractures. Wilderness Environ Med. 2006;17(1):41-8

177. Rowlands TK, Clasper J. The Thomas splint--a necessary tool in the management of battlefield injuries. J R Army Med Corps. 2003;149(4):291-3.

178. Ellerton J, Milani M, Blancher M, Zen-Ruffinen G, Skaiaa SC, Brink B, Lohani A Paal P. Managing moderate and severe pain in mountain rescue. High Alt Med Biol. 2014;15(1):8-14.

179. Wedmore IS, Butler FK Jr. Battlefield analgesia in tactical combat casualty care. Wilderness Environ Med. 2017;28(2S):S109-16.

180. Russell KW, Scaife CL, Weber DC, Windsor JS, Wheeler AR, Smith WR, Wedmore I, McIntosh SE, Lieberman JR, Wilderness Medical S. Wilderness Medical society practice guidelines for the treatment of acute pain in remote environments: 2014 update. Wilderness Environ Med. 2014;25(4 Suppl):S96-104

181. Iserson KV. An hypnotic suggestion: review of hypnosis for clinical emergency care. J Emerg Med. 2014;46(4):588-96.

182. van Kraaij DJ, Hovestad-Witterland AH, de Metz M, Vollaard EJ. A comparison of the effects of nabumetone vs meloxicam on serum thromboxane B2 and platelet function in healthy volunteers. Br J Clin Pharmacol. 2002;53(6):644-7.

183. Marland S, Ellerton J, Andolfatto G, Strapazzon G, Thomassen O, Brandner B, Weatherall A, Paal P. Ketamine: use in anesthesia. CNS Neurosci Ther. 2013; 19(6):381-9.

184. Paix BR, Capps R, Neumeister G, Semple T. Anaesthesia in a disaster zone: a report on the experience of an Australian medical team in Banda Aceh following the 'Boxing day Tsunami'. Anaesth Intensive Care. 2005;33(5):629-34.

185. Karlow N, Schlaepfer CH, Stoll CRT, Doering M, Carpenter CR, Colditz GA Motov S, Miller J, Schwarz ES. A systematic review and meta-analysis of ketamine as an alternative to opioids for acute pain in the emergency department. Acad Emerg Med. 2018;25(10):1086-97.

186. Todd $\mathrm{KH}$. A review of current and emerging approaches to pain management in the emergency department. Pain Ther. 2017;6(2):193-202.

187. Jephcott C, Grummet J, Nguyen N, Spruyt O. A review of the safety and efficacy of inhaled methoxyflurane as an analgesic for outpatient procedures. Br J Anaesth. 2018;120(5):1040-8.

188. Wilkes M, Heath EC, Mason NP. Methoxyflurane for procedural analgesia at 4470 m altitude. Wilderness Environ Med. 2018;29(3):388-91.

189. Wakai A, O'Sullivan R, McCabe A. Intra-articular lignocaine versus intravenous analgesia with or without sedation for manual reduction of acute anterior shoulder dislocation in adults. Cochrane Database Syst Rev. 2011;4:CD004919.

190. Kelly Y, Yonga J. Regional anesthesia of the thorax and extremities. In: Roberts J, Hedges J, editors. Roberts and Hedges' clinical procedures in emergency medicine and acute care. 7th ed. Amsterdam: Elsevier; 2019. p. 560-87.

191. Latifzai K, Sites BD, Koval KJ. Orthopaedic anesthesia - part 2. Common techniques of regional anesthesia in orthopaedics. Bull NYU Hosp Jt Dis. 2008;66(4):306-16.
192. Gadsden J, Warlick A. Regional anesthesia for the trauma patient: improving patient outcomes. Local Reg Anesth. 2015;8:45-55.

193. Kelly J, Younga J. Regional anesthesia of the thorax and extremities. In: Roberts J, Hedges J, editors. Roberts and Hedges' clinical procedures in emergency medicine and acute care. Amsterdam: Elsevier; 2019. p. 560-87.

194. Hards M, Brewer A, Bessant G, Lahiri S. Efficacy of Prehospital analgesia with fascia lliaca compartment block for femoral bone fractures: a systematic review. Prehosp Disaster Med. 2018;33(3):299-307.

195. Buttner B, Mansur A, Kalmbach M, Hinz J, Volk T, Szalai K, Roessler M, Bergmann I. Prehospital ultrasound-guided nerve blocks improve reductionfeasibility of dislocated extremity injuries compared to systemic analgesia. A randomized controlled trial. PLoS One. 2018;13(7):e0199776.

196. Wu JJ, Lollo L, Grabinsky A. Regional anesthesia in trauma medicine. Anesthesiol Res Pract. 2011;2011:713281.

197. Selbst SM, Fein JA. Sedation and analgesia. In: Fleisher GR, Ludwig S, Henretig FM, editors. Textbook of pediatric emergency medicine. 5th ed. Philadelphia: Lippincott Williams and Wilkins; 2006. p. 69.

198. Ireland S, Endacott R, Cameron P, Fitzgerald M, Paul E. The incidence and significance of accidental hypothermia in major trauma--a prospective observational study. Resuscitation. 2011;82(3):300-6.

199. Trentzsch H, Huber-Wagner S, Hildebrand F, Kanz KG, Faist E, Piltz S, Lefering $R$, TraumaRegistry DGU. Hypothermia for prediction of death in severely injured blunt trauma patients. Shock. 2012;37(2):131-9.

200. Strapazzon G, Procter E, Paal P, Brugger H. Pre-hospital core temperature measurement in accidental and therapeutic hypothermia. High Alt Med Biol. 2014;15(2):104-11.

201. Pasquier M, Carron PN, Rodrigues A, Dami F, Frochaux V, Sartori C, Deslarzes T, Rousson $\mathrm{V}$. An evaluation of the Swiss staging model for hypothermia using hospital cases and case reports from the literature. Scand J Trauma Resusc Emerg Med. 2019;27(1):60.

202. Skaiaa SC, Brattebo G, Assmus J, Thomassen O. The impact of environmental factors in pre-hospital thermistor-based tympanic temperature measurement: a pilot field study. Scand J Trauma Resusc Emerg Med. 2015;23:72

203. Haverkamp FJC, Giesbrecht GG, Tan E. The prehospital management of hypothermia - an up-to-date overview. Injury. 2018;49(2):149-64.

204. Henriksson O, Lundgren P, Kuklane K, Holmer I, Naredi P, Bjornstig U. Protection against cold in prehospital care: evaporative heat loss reduction by wet clothing removal or the addition of a vapor barrier--a thermal manikin study. Prehosp Disaster Med. 2012;27(1):53-8.

205. Henriksson O, Lundgren PJ, Kuklane K, Holmer I, Giesbrecht GG, Naredi P, Bjornstig U. Protection against cold in prehospital care: wet clothing removal or addition of a vapor barrier. Wilderness Environ Med. 2015;26(1):11-20.

206. Dow J, Giesbrecht GG, Danzl DF, Brugger H, Sagalyn EB, Walpoth B, Auerbach PS, McIntosh SE, Nemethy M, McDevitt M, et al. Wilderness Medical society clinical practice guidelines for the out-of-hospital evaluation and treatment of accidental hypothermia: 2019 update. Wilderness Environ Med. 2019;30(4S):S47-69

207. Allen PB, Salyer SW, Dubick MA, Holcomb JB, Blackbourne LH. Preventing hypothermia: comparison of current devices used by the US Army in an in vitro warmed fluid model. J Trauma. 2010;69(Suppl 1):S154-61.

208. Zasa M, Flowers N, Zideman D, Hodgetts TJ, Harris T. A torso model comparison of temperature preservation devices for use in the prehospital environment. Emerg Med J. 2016;33(6):418-22.

209. Oliver SJ, Brierley JL, Raymond-Barker PC, Dolci A, Walsh NP. Portable Prehospital methods to treat near-hypothermic shivering cold casualties. Wilderness Environ Med. 2016;27(1):125-30.

210. Zafren K, Giesbrecht GG, Danzl DF, Brugger H, Sagalyn EB, Walpoth B, Weiss EA, Auerbach PS, McIntosh SE, Nemethy M, et al. Wilderness Medical society practice guidelines for the out-of-hospital evaluation and treatment of accidental hypothermia: 2014 update. Wilderness Environ Med. 2014;25(4 Suppl):S66-85.

211. Brooks B, Deakin CD. Relationship between oxygen concentration and temperature in an exothermic warming device. Emerg Med J. 2017; 34(7):472-4

212. Lehavi A, Yitzhak A, Jarassy R, Heizler R, Katz YS, Raz A. Comparison of the performance of battery-operated fluid warmers. Emerg Med J. 2018;35(9): $564-70$

213. Tomazin I, Ellerton J, Reisten O, Soteras I, Avbelj M. International Commission for Mountain Emergency M: Medical standards for mountain rescue operations using helicopters: official consensus recommendations of 
the International Commission for Mountain Emergency Medicine (ICAR MedCom). High Alt Med Biol. 2011;12(4):335-41.

214. Ausserer J, Moritz E, Stroehle M, Brugger H, Strapazzon G, Rauch S, Mair P. International Alpine trauma registry study G: physician staffed helicopter emergency medical systems can provide advanced trauma life support in mountainous and remote areas. Injury. 2017:48(1):20-5.

215. Pasquier M, Geiser V, De Riedmatten M, Carron PN. Helicopter rescue operations involving winching of an emergency physician. Injury. 2012;43(9): 1377-80.

216. Sun H, Samra NS, Kalakoti P, Sharma K, Patra DP, Dossani RH, Thakur JD, Disbrow EA, Phan K, Veeranki SP, et al. Impact of Prehospital transportation on survival in skiers and snowboarders with traumatic brain injury. World Neurosurg. 2017;104:909-18 e908.

217. de Jongh MA, van Stel HF, Schrijvers AJ, Leenen LP, Verhofstad MH. The effect of helicopter emergency Medical services on trauma patient mortality in the Netherlands. Injury. 2012;43(9):1362-7.

218. Galvagno SM Jr, Haut ER, Zafar SN, Millin MG, Efron DT, Koenig GJ Jr, Baker SP, Bowman SM, Pronovost PJ, Haider AH. Association between helicopter vs ground emergency medical services and survival for adults with major trauma. JAMA. 2012;307(15):1602-10.

219. Bekelis K, Missios S, Mackenzie TA. Prehospital helicopter transport and survival of patients with traumatic brain injury. Ann Surg. 2015;261(3):57985.

220. Andruszkow H, Lefering R, Frink M, Mommsen P, Zeckey C, Rahe K, Krettek C, Hildebrand F. Survival benefit of helicopter emergency medical services compared to ground emergency medical services in traumatized patients. Crit Care. 2013;17(3):R124.

221. Zhu TH, Hollister L, Opoku D, Galvagno SM Jr. Improved survival for rural trauma patients transported by helicopter to a verified trauma center: a propensity score analysis. Acad Emerg Med. 2018;25(1):44-53.

222. Stengel D, Rademacher G, Ekkernkamp A, Guthoff C, Mutze S. Emergency ultrasound-based algorithms for diagnosing blunt abdominal trauma. Cochrane Database Syst Rev. 2015;9:CD004446.

223. Price DD, Wilson SR, Murphy TG. Trauma ultrasound feasibility during helicopter transport. Air Med J. 2000;19(4):144-6.

224. Snaith B, Hardy M, Walker A. Emergency ultrasound in the prehospital setting: the impact of environment on examination outcomes. Emerg Med J. 2011;28(12):1063-5.

225. Kirkpatrick AW, Sirois M, Laupland KB, Liu D, Rowan K, Ball CG, Hameed SM, Brown R, Simons R, Dulchavsky SA, et al. Hand-held thoracic sonography for detecting post-traumatic pneumothoraces: the extended focused assessment with Sonography for trauma (EFAST). J Trauma. 2004;57(2):28895.

226. Press GM, Miller SK, Hassan IA, Alade KH, Camp E, Junco DD, Holcomb JB. Prospective evaluation of prehospital trauma ultrasound during aeromedical transport. J Emerg Med. 2014;47(6):638-45.

227. Ketelaars R, Hoogerwerf N, Scheffer GJ. Prehospital chest ultrasound by a dutch helicopter emergency medical service. J Emerg Med. 2013;44(4): $811-7$.

228. Gottlieb M, Holladay D, Peksa GD. Ultrasonography for the confirmation of endotracheal tube intubation: a systematic review and meta-analysis. Ann Emerg Med. 2018;72(6):627-36.

229. You-Ten KE, Siddiqui N, Teoh WH, Kristensen MS. Point-of-care ultrasound (POCUS) of the upper airway. Can J Anaesth. 2018;65(4):473-84.

230. Siddiqui N, Yu E, Boulis S, You-Ten KE. Ultrasound is superior to palpation in identifying the Cricothyroid membrane in subjects with poorly defined neck landmarks: a randomized clinical trial. Anesthesiology. 2018;129(6):1132-9.

231. Quick JA, Uhlich RM, Ahmad S, Barnes SL, Coughenour JP. In-flight ultrasound identification of pneumothorax. Emerg Radiol. 2016;23(1):3-7.

232. Peters J, Ketelaars R, van Wageningen B, Biert J, Hoogerwerf N. Prehospital thoracostomy in patients with traumatic circulatory arrest: results from a physician-staffed helicopter emergency Medical service. Eur J Emerg Med. 2017:24(2):96-100

233. Kearns MJ, Walley KR. Tamponade: hemodynamic and echocardiographic diagnosis. Chest. 2018;153(5):1266-75.

234. Bodson L, Bouferrache K, Vieillard-Baron A. Cardiac tamponade. Curr Opin Crit Care. 2011;17(5):416-24.

235. Schairer JR, Biswas S, Keteyian SJ, Ananthasubramaniam K. A systematic approach to evaluation of pericardial effusion and cardiac tamponade. Cardiol Rev. 2011:19(5):233-8.
236. Co SJ, Yong-Hing CJ, Galea-Soler S, Ruzsics B, Schoepf UJ, Ajlan A, Farand P, Nicolaou S. Role of imaging in penetrating and blunt traumatic injury to the heart. Radiographics. 2011;31(4):E101-15.

237. Huang YK, Lu MS, Liu KS, Liu EH, Chu JJ, Tsai FC, Lin PJ. Traumatic pericardial effusion: impact of diagnostic and surgical approaches. Resuscitation. 2010;81(12):1682-6.

238. Brun PM, Bessereau J, Levy D, Billeres X, Fournier N, Kerbaul F. Prehospital ultrasound thoracic examination to improve decision making, triage, and care in blunt trauma. Am J Emerg Med. 2014;32(7):817 e811-2.

239. McNeil CR, McManus J, Mehta S. The accuracy of portable ultrasonography to diagnose fractures in an austere environment. Prehosp Emerg Care. 2009; 13(1):50-2.

240. Cho KH, Lee SM, Lee YH, Suh KJ. Ultrasound diagnosis of either an occult or missed fracture of an extremity in pediatric-aged children. Korean J Radiol. 2010:11(1):84-94.

241. Robba C, Cardim D, Tajsic T, Pietersen J, Bulman M, Rasulo F, Bertuetti R, Donnelly J, Xiuyun L, Czosnyka Z, et al. Non-invasive intracranial pressure assessment in brain injured patients using ultrasound-based methods. Acta Neurochir Suppl. 2018;126:69-73.

242. O'Dochartaigh D, Douma M. Prehospital ultrasound of the abdomen and thorax changes trauma patient management: a systematic review. Injury. 2015:46(11):2093-102.

243. Zanobetti M, Coppa A, Nazerian P, Grifoni S, Scorpiniti M, Innocenti F, Conti A, Bigiarini S, Gualtieri S, Casula C, et al. Chest abdominal-focused assessment Sonography for trauma during the primary survey in the emergency department: the CA-FAST protocol. Eur I Trauma Emerg Surg. 2018;44(6):805-10

244. Jorgensen $\mathrm{H}$, Jensen $\mathrm{CH}$, Dirks J. Does prehospital ultrasound improve treatment of the trauma patient? A systematic review. Eur J Emerg Med. 2010;17(5):249-53.

245. Anonymous. BET 2: is prehospital focused abdominal ultrasound useful during triage at mass casualty incidents? Emerg Med J. 2013;30(7):596-7.

246. Fragou M, Gravvanis A, Dimitriou V, Papalois A, Kouraklis G, Karabinis A, Saranteas T, Poularas J, Papanikolaou J, Davlouros P, et al. Real-time ultrasound-guided subclavian vein cannulation versus the landmark method in critical care patients: a prospective randomized study. Crit Care Med. 2011;39(7):1607-12.

247. Ketelaars R, Stollman JT, van Eeten E, Eikendal T, Bruhn J, van Geffen GJ. Emergency physician-performed ultrasound-guided nerve blocks in proximal femoral fractures provide safe and effective pain relief: a prospective observational study in the Netherlands. Int J Emerg Med. 2018; $11(1): 12$.

\section{Publisher's Note}

Springer Nature remains neutral with regard to jurisdictional claims in published maps and institutional affiliations.

Ready to submit your research? Choose BMC and benefit from:

- fast, convenient online submission

- thorough peer review by experienced researchers in your field

- rapid publication on acceptance

- support for research data, including large and complex data types

- gold Open Access which fosters wider collaboration and increased citations

- maximum visibility for your research: over $100 \mathrm{M}$ website views per year

At BMC, research is always in progress.

Learn more biomedcentral.com/submissions 